\title{
Grassland ecology in China: perspectives and challenges
}

\author{
Deli WANG (凶), Ling WANG, Jushan LIU, Hui ZHU, Zhiwei ZHONG
}

Key Laboratory of Vegetation Ecology/Key Laboratory of Wetland Conservation and Restoration, School of Environment/Institute of Grassland Science, Northeast Normal University, Changchun 130024, China

\begin{abstract}
During the last few decades, there have been an increasing number of studies on grassland ecology in China, involving the classic ecology concepts or theories and the applicable ecological principles of grassland conservation or management. This paper reviews the main progress in the following aspects. (1) Research on grassland species adaptation and resistance, population dynamics and foraging behavior, and biodiversity and community stability. (2) Research on managed grassland ecosystems (grassland grazing ecology) including grazing effects on grassland ecosystem function and foraging behavior by large herbivores. (3) Global climate change and grassland processes and functioning. (4) Applied research on grassland restoration and ecosystem health assessments such as vegetation restoration, restoration of ecosystem functioning, and assessment methods. There have been significant advances in grassland ecology, including the functions of ecosystem biodiversity, the ecological stoichiometry mechanisms affecting grassland community stability, grazing regulation of plant diversity and nutrient cycling. Grassland ecologists have succeeded in making these advances through observational, experimental and theoretical studies. Nevertheless, there are still significant challenges for the grassland ecology research, including understanding of grassland spatial processes, grassland grazing and multi-functionality, integrated effects of global climate change across grassland areas, as well as the ecological methodology and experimental techniques in grassland ecology.
\end{abstract}

Keywords biodiversity, climate change, China, grazing, meadow, restoration, steppe

\section{Introduction}

The role of ecology in society has increased dramatically in importance over the past century because it provides

Received August 21, 2017; accepted January 19, 2018

Correspondence: wangd@nenu.edu.cn essential information and valuable insights that help us better understand our world. As one of the key areas of ecological study, grassland ecology, referring to the relationships between organisms and their habitats within grassland ecosystems, focuses on the interactions between plants, animals, microbes and soils, and their effects on process and function, from the gene to the population and community levels to the global scale. In recent decades, trends in basic ecological research, such as the theories of plant competition, biodiversity conservation, animal foraging behavior, and nutrient cycling and trophic cascading, originate from grasslands due to their large area that covers about $40 \%$ of total land, their moderate ecosystem complexity, and their ease of manipulation manipulative priority compared to forests, swamps and deserts ${ }^{[1]}$. Grasslands are considered the largest managed ecosystem on earth and are exposed to the combined effects of frequent human activities and ongoing global climate change. The intensive grassland utilization through grazing and mowing during recent decades imposes particularly significant impacts on the productivity of vegetation, composition and biodiversity, and in turn alters the edaphic physicochemical properties, consequently influencing systematic processes and functions.

Grassland ecology was of practical interest in the early 1950s although at that time there was limited research on general ecological aspects in China (Fig. 1). Most work on grassland ecology had concentrated on surveying or investigation of grassland vegetation, including flora, distribution, community composition and productivity, in the north-east and in Inner Mongolian. A pioneering study of the vegetation in parts of Heilongjiang Province provided quantitative vegetation analysis for plant communities or assemblages associated with different soil types $^{[2]}$. This was followed by several studies on the grassland vegetation in meadow steppes and desert steppes ${ }^{[3-6]}$. In the early grassland ecology studies, researchers focused on the plant types and distribution patterns as related to fodder productivity, but paid little attention to the impact of environmental variables such as soil properties and herbivore grazing on grasslands. 
From the 1980s onwards, grassland ecology developed with more researchers engaging in ecology in China, and most importantly, grassland scientists began to explore the grassland as a functional system (Fig. 1), i.e., an ecosystem. Given that one universal feature of all ecosystems is the interaction of autotrophic and heterotrophic components across the ecological hierarchy, the linkages between plants, large herbivores, invertebrates, soil animals and microbial communities and to their habitats, including changes in nutrients, microclimate and physicochemical properties, were often selected as research topics for grassland ecosystems. In the dry steppes, the relationships between biomass and photosynthesis of dominant species (e.g., Leymus and Stipa) and precipitation, air temperature and soil moisture or nutrients, and the population dynamics and diet selection of rodents (voles) and grasshoppers, and soil enzyme activity and microbe biomass were measured and analyzed ${ }^{[7-9]}$. The effects of grazing by livestock and rodents, such as pika and voles, were assessed in the alpine meadows ${ }^{10]}$. There were two prominent focuses for grassland ecology research: (1) conducting long-term or fixed experiments in the north-east (meadow steppe), Inner Mongolia (dry and desert steppe) and Qinghai-Tibetan Plateau (alpine meadow), and (2) making observations or experiments on ecological processes such as energy flow (plant-animal), and nutrient $(\mathrm{C}, \mathrm{N}$ and $\mathrm{P}$ ) and water cycling. The greatest achievements in grassland ecology can be attributed to the above experimental platforms and increasing research funding from the Chinese government (including general or major grants).

Since the beginning of the 21 st century, there has been significant expansion in grassland ecology research in China. Many studies on grassland ecology have addressed the scenarios of global climate change and human activities. This involves the study of long-term field manipulative experiments, including warming, nitrogen deposition, precipitation alteration, and livestock grazing, conducted on various steppes. The focus of these studies has also become much wider, ranging from species adaptive and functional traits, interrelationships between the same or different taxon, and multi-trophic levels (i.e., plant-plant, plant-animal and plant-animal-microbe), and biodiversity, productivity and their relationships. The work on grassland structural features has been strongly related to grassland functions such as nutrient and water cycling (Fig. 1), e.g., carbon sequestration, biodiversity maintenance and system stability. The established and developing hypotheses or theories, such as relationships among biodiversity-productivity-stability, optimal foraging theory, ecological stoichiometry, allometry theory, and food web and trophic cascading, have been frequently tested and refined for grassland ecosystems ${ }^{[11-14]}$, indicating that grassland scientists have contributed substantially to the development of ecology.

\section{Classic ecological research in grasslands}

Many current studies in grassland ecology still focus on the long-established ecological approaches from individual and population, through to community and ecosystem, involving species adaptation and resistance, population dynamics and foraging behavior, as well as biodiversity and community stability.

\subsection{Species adaptation and resistance}

Plant growth and yield in many grassland ecosystems of the world are limited by a wide variety of biotic stress factors, such as salinity, drought, extreme temperature and metal toxicity. Over the past two decades, there have been several key advances in research in China on plant adaptation and resistance.

In grasslands of north-east China, organic acids are important in the physiology of the alkali-tolerant halophyte, Chloris virgate. Under alkali stress, $\mathrm{Na}^{+}$sharply increased, and $\mathrm{NO}_{3}^{-}$and $\mathrm{H}_{2} \mathrm{PO}_{4}^{-}$decreased in shoots,

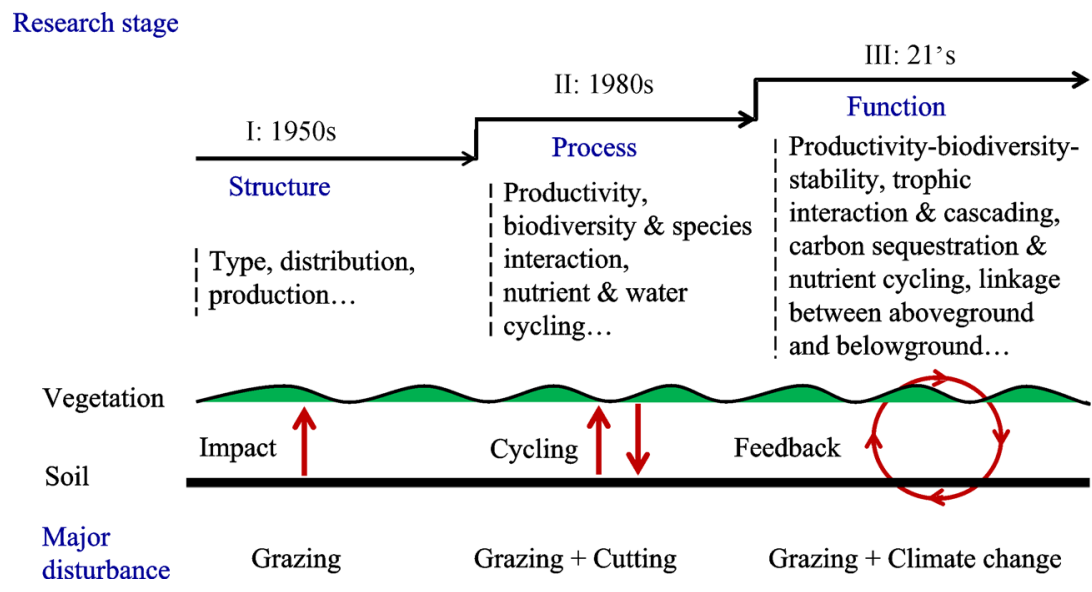

Fig. 1 Outline of the stages in research on grassland ecology in China 
which caused a severe deficit of negative charge $\mathrm{e}^{[15]}$. Achnatherum splendens has an enrichment of salt stressrelated GO category proteins, including those having oxidation-reduction, ion channel transporter and transcription factor activity ${ }^{[16]}$. For Suaeda maritima, Wang et al. ${ }^{[17]}$ proposed two distinct low-affinity $\mathrm{Na}^{+}$ uptake pathways: the first pathway is insensitive to TEA ${ }^{+}$ or $\mathrm{Cs}^{+}$, but sensitive to $\mathrm{Ba}_{2}{ }^{+}$and mediates $\mathrm{Na}^{+}$uptake under low salinity; the second pathway is sensitive to $\mathrm{TEA}^{+}, \mathrm{Cs}^{+}$and $\mathrm{Ba}_{2}{ }^{+}$, and mediates $\mathrm{Na}^{+}$uptake under higher external salt concentrations ${ }^{[17]}$. The grass, Puccinellia tenuiflora, has stronger selectivity for $\mathrm{K}^{+}$over $\mathrm{Na}^{+}$, allowing it to maintain significantly lower tissue $\mathrm{Na}^{+}$and higher $\mathrm{K}^{+}$concentration than that of wheat under short- or long-term $\mathrm{NaCl}$ treatments ${ }^{[18]}$.

Cold stress is one of the most serious plant growth stresses in the world ${ }^{[19]}$. Liu et $\mathrm{al}^{[20]}$. found that brassinosteroids can have a positive effect in the alleviation of oxidative damage caused by reactive oxygen species overproduction through enhancing antioxidant defense system, resulting in improving the tolerance of Chorispora bungeana suspension cultures to chilling stress. Comparative transcriptome analysis suggests that cold acclimation is not a major chilling tolerance mechanism of C. bungeana. Activation of protein phosphorylation and ubiquitination may confer chilling tolerance to C. bungeana in a more rapid and flexible way than cold acclimation ${ }^{[21]}$. Xu et al. ${ }^{[22,23]}$ found that moderate water deficits had positive effects on stomatal number of Leymus chinensis, but more severe deficits led to a reduction, described in a quadratic parabolic curve. In north-west China, ecologists found the two major adaptive strategies used by Zygophyllum xanthoxylum against arid environments are absorbing a great quantity of $\mathrm{Na}^{+}$from low-salinity soil which is efficiently transported to the leaves and maintaining the stability of $\mathrm{K}^{+}$concentration in those leaves ${ }^{[24]}$. For grass pea (Lathyrus sativus), the accumulation of osmoprotectants and the improvement of oxidation resistance is the mechanism that enables higher drought tolerance of grass pea than field pea ${ }^{[25]}$.

\subsection{Population dynamics and foraging behavior}

Plant population ecology is one of the most important branches of ecological research. During the past 40 years, the basic theory and research methodology in plant population ecology has developed rapidly in China. Plant modular ecology is the study of the interactions among plant modular organisms and the population statistics characteristics of plants under different environments ${ }^{[26]}$. In Songnen grasslands in north-eastern China, Yang and Zhang ${ }^{[27]}$ investigated the seasonal dynamics of vegetative propagation of $L$. chinensis, a perennial rhizome grass in the region. They found that $L$. chinensis grass could continuously vegetatively propagate during the whole growing season (from May to August). Yang et al. ${ }^{[28]}$ further investigated the age structure of this perennial grass and found that most of the tillering nodes of $L$. chinensis were four-year old, with some of five-year old. Finally, Yang and $\mathrm{Li}^{[29]}$ quantified the ecological plasticity of the seedheads of $L$. chinensis and found that either the length of seedheads or number of spikelets of this grass varied significantly both within and between years.

Seed is the reproductive body of spermatophytes, and resource devotion to its production has a direct effect on the offspring fitness and the renewal of vegetation communities. In Korqin sandland, Inner Mongolia, eight species, e.g., Clinelymus dahuricus, Cleistogenes squarrosa, Pappophorum boreale, had a germination rate of over $80 \%$, but four species, e.g., Echinochloa hispidula and Hemarthria compresa, had a rate of less than $10 \%{ }^{[30]}$. In semi-arid grasslands of northern China, the seedling emergence of $L$. secalinus was affected by the amount and frequency of monthly precipitation and depth of burial, and emergence decreased with reduced frequency for the same precipitation amount ${ }^{[31]}$. In dune ecosystems, the size of the aerial seed bank was higher than that of the soil seed bank throughout the growing season. Seed release was positively related to wind velocity ${ }^{[32]}$.

Rhizomes are important for many processes, including asexual reproduction, communication and resource sharing between ramets, and foraging in heterogeneous environments. Clonal plants are commonly more tolerant to grazing than co-occurring non-clonal plants in inland dunes. Compared with the control, heavy clipping greatly increased the relative growth of Bromus and Psammochloa, but decreased that of Artemisia and Astragalus ${ }^{[33]}$. Under moderate clipping, rhizome connection significantly improved the performance of Psammochloa, but not that of Bromus. Heavy clipping reduced ramet, leaf and biomass density in the disconnected plots of both species, but such negative effects were negated or greatly ameliorated when the rhizomes were connected ${ }^{[34]}$. These results suggest that clonal integration is an additional compensatory mechanism for clonal plants and may be important for their long-term persistence in the heavily grazed regions in northern China. In sandland environments, plants experience substantial variation in growing conditions during the dune fixation process, with high sand mobility in early stages and denser vegetation cover in later stages. $\mathrm{Li}$ et al. ${ }^{[35]}$ studied the changes in demography of the dominant shrub, Artemisia ordosica, at three stages of dune fixation: semi-fixed dunes, fixed dunes and fixed dunes covered with microbiotic crust. They found that plant growth and reproduction decreased strongly as dunes became more fixed. Reduction in plant height occurred quite often, particularly in the fixed dunes with microbiotic crust. It is hypothesized that the benefits of clonal integration can vary depending on whether patchiness is reciprocal or coincident, and that clonal species experience greater benefits from integration when qualitative patterns of resource heterogeneity are more like those likely to 
occur in their habitats. To test these hypotheses, He et al. ${ }^{[36]}$ grew pairs of connected ramets of Cynodon dactylon and Potentilla reptans under high and low levels of light, water and soil nutrients, and measured growth and physiological traits of the plants. Consistent with the hypotheses, they found that connection between ramets in contrasting patches increased final dry mass of Cynodon by $30 \%$ compared with connection between ramets within the same type of patch when resource patchiness was coincident, whereas connection decreased mass by $60 \%$ when patchiness was reciprocal.

\subsection{Biodiversity and community stability}

Ecosystem structure, functioning and stability have been a focus of ecological and environmental sciences during the past decades. The mechanisms underlying their relationship, however, are not well understood. Based on a 24-year study of the Inner Mongolia grassland, Bai et al. ${ }^{[11]}$ presented three key findings concerning ecosystem stability and compensatory effects in the grassland. Firstly, that January-July precipitation is the primary climatic factor causing fluctuations in community biomass production; secondly, that ecosystem stability increases progressively along the hierarchy of organizational levels; and finally, that the community-level stability seems to arise from compensatory interactions among major components at both species and functional group levels. This study provided new insights for better management and restoration of the rapidly degrading Inner Mongolia grassland. Bai et al. ${ }^{[37]}$ further investigated the spatial and temporal patterns of ANPP (aboveground net primary production) and RUE (rain use efficiency) and their key driving factors based on a long-term data set from 21 natural semi-arid and arid ecosystem sites across the Inner Mongolia steppe region in northern China. Their results showed that, with increasing mean annual precipitation, ANPP increased while the inter-annual variability of ANPP declined, plant species richness increased and the relative abundance of key functional groups shifted predictably, and RUE increased in space across different ecosystems but decreased with increasing annual precipitation within a given ecosystem. These results clearly indicate that the patterns of both ANPP and RUE are scale dependent, and the seemingly conflicting patterns of RUE in space vs. time suggest distinctive underlying mechanisms, involving interactions among precipitation, soil $\mathrm{N}$ and biotic factors. Also, while their results supported the existence of common maximum RUE, they also indicated that its value could be substantially increased by altering resource availability, such as adding nitrogen.

The mechanisms underlying the relationships among ecosystem structure, functioning and stability have been a focus of ecological and environmental sciences during the past two decades. Based on comprehensive studies on Inner Mongolia grassland, Yu et al. ${ }^{[13]}$ found that species- level stoichiometric homeostasis was consistently and positively correlated with dominance and stability on both 2-year and 27-year temporal scales, and across a 1200-km spatial transect. At the community level, stoichiometric homeostasis was also positively correlated with ecosystem function and stability in most cases. Thus, homeostatic species tend to have high and stable biomass; and ecosystems dominated by more homeostatic species have higher productivity and greater stability.

\section{Research on managed grassland ecosystems - grazing ecology}

Livestock grazing is one of the most prevalent land uses of grassland. Currently, a majority of grasslands are experiencing overgrazing in China, which severely threatens productive and ecological function of grasslands. Therefore, grassland grazing ecology is one of the key fields of research in grassland ecology. Over the past 30 years, extensive observational and empirical studies on livestock grazing effects on structure and function of grassland ecosystem have been conducted in China. We searched peer-reviewed journal articles published during 19852017 on livestock grazing effects using Scopus and China Knowledge Resource Integrated Database. A total of 1704 papers were found, with 1023 papers published in Chinese periodicals and 681 papers in international periodicals. The total number of published paper in grazing ecology increased substantially every year since 1985 (Fig. 2). For example, only five studies on grassland grazing effects were published during 1985-1990 while a total of 741 were published during 2010-2015. These studies involved grazing-induced changes in vegetation characteristics, soil properties, soil biota and other trophic level biota (e.g., insects), and also productivity, nutrient cycling and grassland $\mathrm{C}$-fixation function. Moreover, many factors were considered, including grazing intensity, grazing time

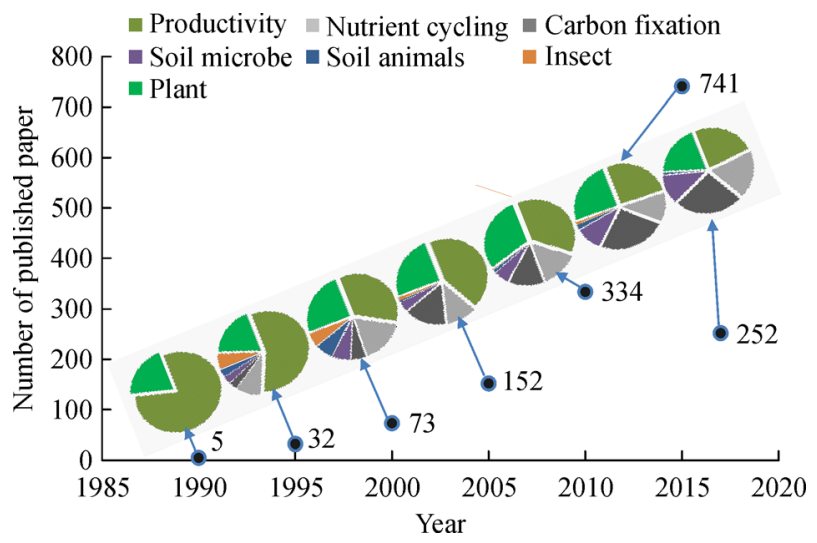

Fig. 2 Number of published papers on livestock grazing effects on grassland structure and function with different keywords every 5 years since 1985 
and season, grazing history, rotational grazing regime, and interactive effects of grazing and the other climate factors (Fig. 3).

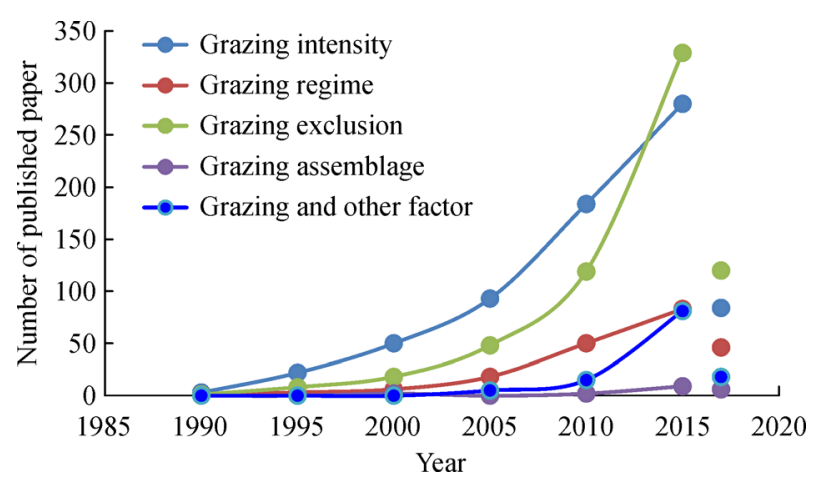

Fig. 3 Number of published papers on livestock grazing with different keywords effects on grassland every 5 years since 1985

3.1 Livestock grazing effects on grassland ecosystem structure

Effects of livestock grazing on vegetation characteristics was the focus, especially in early research stage (Fig. 2), because vegetation is not only the basis for grassland ecosystem function and also the component most directly disturbed by livestock grazing. Over the past 30 years, a large number of studies quantitatively evaluated the effects of different grazing intensities on grassland plant composition and diversity, which have considerably improved our understanding of grazing effects. In all studies, overgrazing has been consistently shown to negatively affect plant diversity across all the grassland types ${ }^{[38,39]}$. Based on intermediate disturbance hypothesis, moderately grazing also has been demonstrated in some studies to contribute to sustain and even improve plant species diversity ${ }^{[40,41]}$. In contrast, a recent study found a U-shaped relationship between diversity an grazing intensity suggesting that diet selection of grazing animals is an important factor shaping the relationship between diversity and grazing intensity in semi-arid grasslands ${ }^{[42]}$. A recent review synthesized 61 studies on grazing effects on plant diversity of alpine grassland in the Qinghai-Tibetan Plateau, and concluded that grazing contributes to greater plant species diversity, but reduced aboveground biomass ${ }^{[43]}$. It remains controversial whether moderate grazing benefits grassland plant diversity. Plant functional traits are found to be closely related to plant function ${ }^{[44]}$. Recent studies have focused mostly on leaf-level traits or community-level weighted traits to predict species responses to grazing $^{[45,46]}$.

Livestock grazing can also have important influences on belowground organisms as well as on vegetation ${ }^{[47,48]}$. Since 2000s, with the development of molecular technique, more studies have begun to investigate changes in soil microbe after grazing disturbance ${ }^{[49,50]}$. A recent study deeply analyzed effects of grazing on soil microbial functional gene ${ }^{[51]}$, and found that grazing increased expression of $\mathrm{N}$ mineralization and nitrification genes but decreased denitrification and N-reduction genes in Tibetan alpine grassland, which will potentially regulate soil $\mathrm{N}$ and $\mathrm{C}$ cycling ${ }^{[52]}$. Furthermore, the mechanisms whereby grazing effects the soil microbial community have also begun to be explored in recent studies. For example, Liu et al. ${ }^{[53]}$ for the first time disentangled the pathways of livestock grazing effects on soil microbes through defoliation and trampling, and found trampling increased the abundance of fungi and AMF, and trampling with defoliation further decreased the abundance of soil microbes. We found only a single study has examined the response of soil fauna to livestock grazing in $\mathrm{China}^{[54]}$.

Controlling outbreaks of grasshoppers in grassland ecosystems has been the subject of particular research emphasis in China. However, relatively fewer studies have investigated effects of grazing on grassland insect communities, such as grasshoppers (Fig. 2). Most studies on grazing effects on grasshoppers were conducted during the period 1994 to 1996 . These studies showed that livestock grazing-induced changes in the plant community can directly affect grasshopper species composition and community structure ${ }^{[55-58]}$. In the last 5 years, some significant progress has been made in understanding the effects of grazing on insect communities. An important study of the Inner Mongolia grassland found that heavy livestock grazing could promote locust outbreaks by lowering plant nitrogen content ${ }^{[59]}$. Zhong et al. ${ }^{[60]}$ also found that there was a positive interaction between sheep and grasshoppers in meadow steppe of north-east China, which further indicated that overgrazing will increase grasshoppers abundance. Furthermore, it was found that grazing by large herbivores can affect insect diversity by modifying plant structural heterogeneity ${ }^{[61]}$. Recently, there is increasing concern that herbivore grazing can interact with climate factors (such as precipitation) to affect insect community at a landscape scale ${ }^{[62,63]}$. These studies indicated that appropriate land use management practices would be beneficial for reducing outbreaks of the dominant pest grasshopper in Inner Mongolia, and different management approaches are necessary depending on the average annual precipitation ${ }^{[62,63]}$ and plant diversity before grazing $^{[64]}$.

\subsection{Grazing effects on grassland ecosystem function}

Productivity is an important indicator for ecosystem function. Most studies found that continuous grazing decreased aboveground and belowground biomass and net primary productivity, and the effects were strengthen at greater grazing intensities ${ }^{[65-67]}$, probably because continuous grazing reduced the source size of carbon- 
assimilating organs and intensified the re-translocation of root carbohydrates to shoot meristems ${ }^{[68]}$. Some studies showed that aboveground biomass was increased by intermediate grazing compared to light and heavy grazing, while belowground biomass was decreased ${ }^{[69,70]}$. In addition, compared with continuous grazing, it was found that rotational grazing can increase the aboveground biomass and productivity of grassland vegetation ${ }^{[71,72]}$.

Abundant evidence indicates that grazing affects plant productivity $^{[41,62,73-75]}$. Relatively few studies in China, however, have examined effects of grazing on nutrient cycling, which determines plant community composition, production rates, levels of biodiversity, and the trophic structure of ecosystems ${ }^{[76,77]}$. Grazing may increase or decrease nutrient cycling by feeding preferentially on different forage species, which produce relatively fast or slow decomposing plant litter, or by direct input of urine and faces into the system ${ }^{[78,79]}$. Shan et al. ${ }^{[80]}$ found in the Inner Mongolia grassland that the effects of grazing intensity on net $\mathrm{N}$ mineralization exhibit strong seasonal dependence, and concluded that grazing at moderate to high intensities will slow down soil $\mathrm{N}$ cycling in the peak growing season. In contrast, a study across a precipitation gradient along the $700 \mathrm{~km}$ China-Mongolia transect, showed that long-term grazing dramatically increased $\mathrm{N}$ content and decreased $\mathrm{C}: \mathrm{N}$ ratios in all plant compartments, suggesting accelerated $\mathrm{N}$ cycling ${ }^{[81]}$. Furthermore, the latest study in meadow steppe in north-east China demonstrated that livestock grazing at moderate intensity exerted predominantly positive effects on soil $\mathrm{N}$ cycling regardless of grazing livestock species and grassland plant diversity context, and the facilitating effect was to a large extent driven by animal waste flowing to the soil ${ }^{[82]}$. The effects of grazing on soil $\mathrm{P}$, especially available $\mathrm{P}$, is less well studied, even though it may be a major limiting factor for plant growth, especially in Kobresia meadows ${ }^{[33]}$.

Over the last decade, increasing studies have started to investigate the effects of grazing on grassland $\mathrm{C}$ fixation. Grazing mostly decreased soil organic carbon (SOC) ${ }^{[84]}$, but under certain conditions moderate grazing increased SOC in the Inner Mongolian steppe $\mathrm{e}^{[85-87]}$ and alpine meadows ${ }^{[88]}$. Decreased SOC can be explained by several pathways. First long-term overgrazing usually causes declines in net primary production ${ }^{[89,90]}$, which decreases the carbon input to soils. Secondly, livestock grazing reduces SOC by reducing the quantity of resources returned to the soil, particularly by removing the palatable grasses and sedges that produce higher-quality litter for decomposers than unpalatable species ${ }^{[91]}$. Also, grazing decreased SOC through higher loss of carbon to the atmosphere as a result of higher soil temperature, and increased soil biota and root activities after grazing ${ }^{[92,93]}$. Furthermore, over long time periods, grazing can result in soil compaction, altering soil infiltration rates, increasing soil bulk density, decreasing soil porosity and increasing soil erosion by wind, which leads to alterations in $\mathrm{SOC}^{[94]}$.
Effects of grazing on belowground $\mathrm{C}$ storage remain uncertain due to methodological difficulties and spatial heterogeneity ${ }^{[95]}$.

\subsection{Foraging behavior of large herbivores}

The understanding of interactions between grassland plant and grazing herbivore is crucial for the theoretical basis for grassland management. Grazing herbivores affect plant communities and edaphic processes by selectively removing biomass, physical disturbance, and excreting nutrients in dung and urine, thereby affecting grassland ecosystem function. Foraging behavior of herbivores, and diet selection in particular, has the most direct influence on the diversity and population dynamics of plant communities $^{[96]}$. One of the main challenges of studying grazing ecology is to predict diet selection and intake of herbivore.

Research on foraging behavior in China prior to 2010 was mostly concerned with preliminary observation and description of foraging time, walking time, rumination activity and diet preference of grazing animals in free rangeland ${ }^{[97]}$. During this period, the relationship between herbivore consumption and plant characteristics, such as structure, morphology, primary and secondary chemistry, and plant density and height, have been well established ${ }^{[98,99]}$. From the 2010 s, comprehensive studies of evolutionary relationships between foraging strategies of grazing animals and vegetation heterogeneity were conducted in grassland ecosystems. An important finding showed that plant species richness in grasslands, will increase food consumption of herbivores and enhance nutrient intake by modifying nutrient balance, toxin dilution and taste modulation ${ }^{[12]}$. Higher plant species richness simultaneously intensifies herbivore diet switching frequency, and weakens herbivore ability to select food, thereby increasing foraging cost and disturbing herbivore selection of plants ${ }^{[12]}$. Another study found that the random dispersion of less preferred species in grasslands may reduce herbivore consumption of highly preferred species, thus minimizing selective grazing ${ }^{[100]}$. High complexity of a spatial neighborhood also can result in herbivores passively reducing selectivity, thereby reducing the probability of damage to palatable species in the community ${ }^{[101]}$. It was found that there may be a weak positive feedback between plant species richness and herbivore foraging, and suggested that increasing plant diversity, especially plant functional group diversity, can reduce herbivore selectivity and promote more uniform use of different plant species in rangelands ${ }^{[102]}$.

3.4 The factors affecting grazing effects on grassland structure and function

The varying effects of grazing on grassland structure and function may be in part attribute to grazing intensity ${ }^{[73,103-105]}$, grazing system and grassland 
types ${ }^{[71,86,106]}$, which are also regulated by climate factors. For example, in a typical steppe, plant production in rotational grazing was higher than in continuous grazing in a drought year, whereas there was no significant difference in two grazing systems in a normal year ${ }^{[86]}$. During the past 30 years in China, more research effort has been directed to examining the effects of grazing intensity or enclosure on grassland structure and function (Fig. 3). Notable progress has been made in understanding the negative effects of overgrazing. From various grazed systems, overgrazing has been shown to negatively affect vegetation structure, diversity and ecosystem function, while light or moderate grazing has neutral or even positive effects ${ }^{[107]}$. However few studies attempt to consider how to further develop adaptive grazing management to maintain and improve grassland function under moderate grazing intensity. Different herbivore species have different foraging behaviors and patch preferences ${ }^{[108]}$, which could have varying effects on species diversity and ecosystem function $^{[109-111]}$ even under same grazing intensity. Furthermore most natural grasslands are grazed by more than one species of herbivore. Herbivore species within a grazer assemblage can compete with each other or the presence of one can facilitate that of another ${ }^{[112]}$. Whether and how herbivore assemblages modify grazer impacts on biodiversity and ecosystem function has rarely been examined in managed ecosystems ${ }^{[113,114]}$. We also found that only a few studies in China have considered the effects of herbivore assemblage (i.e., different herbivore species and combinations). These studies showed that the effects of grazing strongly depend on herbivore assemblages, and suggested that multiple-species grazing regimes in grassland systems could represent the optimal choice for grazing management ${ }^{[82,115,116]}$. Moreover, more and more studies have focused on interactive effects of grazing herbivore and climate change, such as $\mathrm{N}$ deposition and precipitation (Fig. 3).

\section{Global climate change and grassland process and function}

Global climate change is considered to be an uncontroversial fact that strongly affects terrestrial ecosystems ${ }^{[117]}$, especially grasslands. The responses of all grassland components to global climate change still need to be given more attention, and the responses of grassland ecosystems need to be studied from a perspective of plants, animals and soil.

\subsection{Responses of plants}

At an individual plant level, climate change can have strong effects. Photosynthesis is the fundamental basis for carbon accumulation, growth and biomass production of plants, and some studies have shown that most of the species in temperate steppe can acclimate to a warmer environment, and photosynthetic responses of plants to warming were species-specific, such as for $\mathrm{C}_{3}$ and $\mathrm{C}_{4}$ plants ${ }^{[118]}$. Beside photosynthesis, plant respiration is key to determining carbon exchange in leaves, plants and ecosystems ${ }^{[119]}$, therefore, when examining the carbon cycling under climate warming, it is necessary to understand thermal acclimation of leaf dark respiration ${ }^{[120]}$. Phenology is one of most sensitive traits of plants in response to climate warming ${ }^{[121]}$, and warming response of plant phenology is larger in earlier than later flowering species in temperate grassland systems ${ }^{[122]}$. Apart for warming, nitrogen deposition is another factor affected by climate change with spatial and temporal distribution of plant roots responding differently to soil $\mathrm{N}$ availability ${ }^{[37]}$.

A growing body of evidence from long-term observational $^{[123]}$ and experimental ${ }^{[124,125]}$ studies has demonstrated that climate change has the potential to alter plant community structure and composition. Some studies found that indirect effects of warming on plant community composition are mediated by altering water availability ${ }^{[126]}$, but $\mathrm{N}$ addition and increased precipitation significantly altered plant community structure and composition through both abiotic (e.g., soil moisture and temperature) and biotic factors (e.g., plant traits and herbivory $)^{[123]}$. Functional and species diversity have opposite responses to short-term fertilization, with increases in functional diversity and decrease in species diversity ${ }^{[127]}$. Moreover, nitrogen effects on plant species diversity depends on water availability ${ }^{[128]}$, links to metal mobilization in soil and differential metal acquisition ${ }^{[129]}$, and results from both acidification and ammonium toxicity ${ }^{[130]}$.

\subsection{Responses of productivity and stability}

To what extent climate change impacts terrestrial plant growth and biomass accumulation ${ }^{[37,131]}$, and the observed responses of plant biomass and/or NPP of terrestrial ecosystems to experimental warming have been considered in recent reports ${ }^{[132,133]}$. Lin et al. ${ }^{[134]}$ found by meta-analysis that warming significantly increased biomass by $12.3 \%$ and that this effect depends upon PFTs (plant functional types), with significantly greater stimulation of woody $(26.7 \%)$ than herbaceous $(5.2 \%)$ species. However, experimental warming decreased annual root production ${ }^{[135]}$. Climate warming is expected to result in unequal changes in day and night temperatures ${ }^{[136]}$, asymmetrical warming may have significant effects on root growth, mortality and turnover ${ }^{[137]}$.

Stability is an important property of ecological systems, and community temporal stability was found to be mainly driven by water and $\mathrm{N}$ availability that modulated the degree of species asynchrony and, to a lesser extent, by the stability of dominant plant species ${ }^{[138,139]}$, and ecosystem stability were positively associated with population 
stability and the residuals of population stability under $\mathrm{N}$ $\operatorname{addition}^{[140]}$.

Some studies found that daytime, but not nighttime, warming significantly reduced community temporal stability mainly through the reduction in the abundance of stable dominant species ${ }^{[141]}$. The relationship between biodiversity and ecological stability is a longstanding issue in ecology, and has gained renewed interest among ecologists because of environmental change. Through a 7-year grassland experiment, Yang et al. ${ }^{[142]}$ found that mowing and nutrient addition did not alter these positive diversity-stability relationships.

\subsection{Responses of nutrient cycling}

Climate change regulates almost all biogeochemical processes, and will therefore have a profound effect on ecosystem functions such as cycling of $C$ and $\mathrm{N}^{[143,144]}$. Asymmetrical warming affected soil respiration through different pathways. There were no direct positive effects of day warming due to increased temperature, but there were indirect negative effects via aggravating water limitation and suppressing ecosystem $\mathrm{C}$ assimilation. Positive effects due to night warming included the stimulation of ecosystem C uptake and substrate supply via overcompensation of plant photosynthesis ${ }^{[145]}$. Soil moisture is an important determinant for altering soil respiration, especially under climate warming ${ }^{[146]}$. $\mathrm{N}$ addition either increased or decreased soil respiration, and such effects strongly depend on $\mathrm{N}$ level ${ }^{[147]}$.

In semi-arid grassland, plant foliar $\mathrm{N}$ and $\mathrm{P}$ concentrations, resorption efficiency and proficiency can respond differently to these resources changes. $\mathrm{N}$ addition and water addition increased $\mathrm{N}$ concentration but had no effect on $\mathrm{P}$ concentration in green leaves. Both $\mathrm{N}$ addition and water addition reduced plant $\mathrm{N}$ resorption proficiency. $\mathrm{N}$ addition increased and water addition had no effect on $\mathrm{P}$ resorption proficiency ${ }^{[148]}$. $\mathrm{N}$ and $\mathrm{P}$ availability in soil and $\mathrm{N}$ and $\mathrm{P}$ concentrations in green and senesced grass leaves increased with increasing rates of $\mathrm{N}$ addition. Foliar $\mathrm{N}$ and $\mathrm{P}$ resorption significantly decreased along the $\mathrm{N}$ addition gradient, implying a resorption mediated, positive plantsoil feedback induced by $\mathrm{N}$ inputs ${ }^{[149]}$.

Loss of plant diversity with increased anthropogenic $\mathrm{N}$ deposition in grasslands has occurred globally. Tian et al. $^{[129]}$ provided evidence from a 9-year $\mathrm{N}$-addition experiment for an alternative mechanism: differential sensitivity of forbs and grasses to increased soil manganese levels. In Inner Mongolian steppes, increasing the N supply shifted plant community composition from grassforb codominance to exclusive dominance by grass, with associated declines in overall species richness. In addition to $\mathrm{N}$ deposition, higher aridity and more extreme rainfall events in dryland areas are predicted with climate change. Wang et al. ${ }^{[150]}$ investigated soil $\mathrm{N}$ isotopic values $\left(\delta^{15} \mathrm{~N}\right)$ along a $3200 \mathrm{~km}$ aridity gradient and revealed a hump- shaped relationship between soil $\delta^{15} \mathrm{~N}$ and aridity index. Precipitation increased the total leaf area of Stipa grandis primarily by increasing leaf numbers; however, elevated $\mathrm{CO}_{2}$ increased the total leaf area of this species by enlarging single leaf area ${ }^{[151]}$. Elevated $\mathrm{CO}_{2}$ stimulated plant biomass of Agropyron cristatum to a greater extent under moderate changes in water status than under either extreme drought or overly wet conditions ${ }^{[152]}$.

\subsection{Responses of soil biotic}

A number of studies have shown that soil microorganisms are key in determining carbon exchange in terrestrial ecosystems $^{[153]}$, and soil microbes are affected by climate change ${ }^{[154,155]}$. By experimental manipulation of precipitation, warming and $\mathrm{N}$, colimitation of microorganisms on soil microbes was found where water is a primary limiting factor, and $\mathrm{N}$ addition positively affected soil microorganisms only when water is sufficient ${ }^{[156]}$. Arbuscular mycorrhizal fungal (AMF) form symbiotic associations with more than $80 \%$ of terrestrial plant species, and are an important part of soil microflora. Warming had a significant positive effect on AMF diversity, but $\mathrm{N}$ addition significantly altered the AMF community composition ${ }^{[157]}$. In a 6-year fertilization experiment, $\mathrm{N}$ fertilization significantly altered the AMF communities but had no obvious influence on AMF abundance. However, P fertilization showed no significant influence on the AMF community structure, but induced a significant decrease in mycorrhizal colonization rate, arbuscular colonization and hyphal length density ${ }^{[158]}$.

In addition to microflora, soil fauna is important in regulating ecosystem processes and functions ${ }^{[159]}$, and strongly responded to global climate change. Experimental warming had slightly negative but insignificant effects on mites and Collembola, but increased precipitation greatly enhanced their abundance ${ }^{[160]}$. Nematode abundance was significantly increased by $\mathrm{N}$ fertilization, but nematode generic richness declined ${ }^{[161]}$, and the effects of $\mathrm{N}$ additions on soil nematode communities were independent of water ${ }^{[162]}$.

\subsection{Responses of insects}

As poikilothermal animals, insects are sensitive to climate change. With elevated temperature, most grasshopper species in Inner Mongolian grasslands are likely to extend their distribution northward with warming ${ }^{[163]}$. Warming may shift animal spring phenology and population dynamics ${ }^{[164]}$, and these effects may depend on variations in precipitation ${ }^{[165]}$. Besides phenology, warming decreased the body size (adult body mass) of insects early in the growing season (May-September) but increased the size late in the growing season, regardless of host-plant identity ${ }^{[166]}$. Due to close relationships between plants and insects, altered plant community 
composition under warming strongly affected insect communities, importantly it enhanced the positive effects of plant diversity on insect diversity ${ }^{[167]}$, and altered precipitation shifted insect community-dominated herbivores to predators ${ }^{[168]}$.

\section{Grassland restoration}

Grassland restoration in China started in 1980s, when Liu and colleagues in Inner Mongolia University studied the restoration succession of degraded grasslands in Inner Mongolia $^{[169]}$. This study pioneered the study of grassland ecosystem degradation succession status in China, with the longest continuous research on the grassland dynamics in China. Studies of grassland restoration before 2000 mainly focused on vegetation succession, and later studies on the restoration process and mechanisms and the recovery of ecosystem functioning. With the implementation of a suite of projects, including returning farmland to forest and grassland, the recovery of biodiversity and ecosystem service has been the two main goals of grassland restoration.

\subsection{Vegetation restoration}

Plant community succession characteristics, especially grassland productivity, are the basal indicators for the evaluation of grassland ecosystems. Before 1990, there was little work on grassland restoration and the in situ study of Liu from 1983 in a typical Xilin Gol steppe dominated by L. chinensis and S. grandis was the most outstanding research at that time. They found that there was a great difference in plant biomass between the severely degraded grassland and the control, and plant productivity was close to that before degradation after the restoration for $8-10$ years ${ }^{[170,171]}$. Wang et al. ${ }^{[172]}$ suggested that plant colonization ability and resource availability in the environments are the two driving forces in restoring a degenerated grassland. In some ecosystems, light to moderate livestock grazing and other techniques, such as mowing, were found to benefit grassland restoration ${ }^{[173]}$. Vegetation succession during restoration was also explored in other grasslands, such as Horqin sandland $d^{[174,175]}$, Alashan desert steppe ${ }^{[176]}$, alkaline meadow $^{[177]}$ and Loess Plateau ${ }^{[178]}$.

Beyond productivity, there was further research, including plant diversity ${ }^{[166]}$, growth strategies ${ }^{[179]}$, spatial pattern of plant communities and dominant species ${ }^{[175,177]}$, and resilience after extremely aridity disturbance ${ }^{[180]}$. Enclosing increased plant diversity through enhancing species richness, and the mechanisms of ecological restoration of desert steppe were the increased reproduction of several species and the full use of surplus resources ${ }^{[176]}$. In Horqin sandland, most species were spatially aggregated, which had the advantage of promoting population invasion and inhabitation, community formation and vegetation restoration. In the process of community succession, the change in the intensity of distribution pattern and community aggregation was in accordance with population dynamics and spatial heterogeneity of community structure ${ }^{[175]}$. In a long-term grazing exclusion experiment on the Loess Plateau, it was found that the succession during the recovery process could be divided into four stages ${ }^{[181]}$. During the process of community succession, the community coverage, plant density, species richness, diversity index, and aboveground biomass increased gradually, with aboveground biomass reaching a maximum $\left(521 \mathrm{~g} \cdot \mathrm{m}^{-2}\right)$ after 12 years and belowground biomass after 15 years. They suggested that degraded grassland could be utilized by mowing once every 2 years or light grazing after being fenced for 10-15 years. By analyzing the difference between grazing and enclosure from 1992 to 2006 in degraded grassland of Horqin sandland, Zhao et al. ${ }^{[174]}$ found that after enclosure to prevent grazing, there was a greater difference in restoration of vegetation between grasslands of different original grazing intensities; the more severe the original grazing the faster the restoration. Plant height, coverage and biomass were more rapidly restored than species richness, diversity and frequency. The restoration process was significantly affected by climate change, and a warm and wet climate was beneficial for the restoration of degradation vegetation, and a warm and dry climate was detrimental.

\subsection{Ecosystem functioning restoration}

Ecosystem functioning and services are the benefits people gain from ecosystems, including a multitude goods and services that maintain and improve human well-being, and these functions and services are essential for regional landscape sustainability ${ }^{[182,183]}$. Climate change, habitat loss, pollution, overexploitation and invasive species are the main causes of biodiversity loss and ecosystem degeneration, leading to reduced provision of ecosystem services $^{[184]}$. Ecological restoration, designed to recover and reestablish the characteristics of an ecosystem that has been degraded, damaged or destroyed, is now recognized as an important strategy to mitigate human pressures on natural ecosystems ${ }^{[185]}$.

Compared to vegetation restoration, the recovery of ecosystem functioning has attracted less attention in research on grassland restoration. In Songnen grassland, $\mathrm{Li}$ and Zheng ${ }^{[186]}$ first reported response of SOC to enclosing and other treatments. In Horqin sandland, Chuan et al. ${ }^{[187]}$ found that soil nutrient availability was also improved together with recovery of vegetation. In a degraded sandy grassland, enclosing could contribute to carbon sequestration and moderate grazing enhanced the carbon $\operatorname{sink}^{[188]}$. With increasing time of vegetation restoration on the Loess Plateau, soil microbial carbon 
and respiration significantly increased, and soil respiration was less affected by plant growth ${ }^{[189]}$. After enclosing a desert grassland for 13 years, livestock exclusion improved soil organic matter, macro nutrients and trace elements, soil texture and carbon sequestration potential, however, it was estimated it would take at least 100 years for carbon stock to be restored to that of non-dersertified grassland ${ }^{[190]}$. Other functions of grassland, including soil respiration, $\mathrm{CO}_{2}$ exchange, carbon emission, carbon and nitrogen stock and water conservation, have also been evaluated in recent years $^{[191-193]}$. Apart from ecosystem functioning, biodiversity has also been studied over the last decade. The soil microbe and animal diversity were surveyed in sandy and alkaline-saline grasslands ${ }^{[194-198]}$.

\subsection{Grassland restoration models}

Ecological restoration is "intentional activity that initiates or accelerates the recovery of an ecosystem with respect to its health, integrity and sustainability" ${ }^{\prime[199]}$. Restoration ecology emerged as a separate field in ecology in the 1980 s, and is the academic study of the process, whereas ecological restoration is the actual project or process carried out by restoration practitioners. Based on the theoretical research, some practical techniques for grassland restoration have been developed for some types of degraded grassland, especially the alkaline-saline grassland in the Songnen Plain and degraded black-soil grassland on the Qinghai-Tibetan Plateau.

The western Songnen Plain is one of China's most important alkaline-saline areas and has been increasing in size by $20000 \mathrm{hm}^{2} \cdot \mathrm{yr}^{-1}$ as a result of natural and anthropogenic factors, which is impeding economic development in the area. Zhu and colleagues in Northeast Normal University began the grassland research in the $1950 \mathrm{~s}^{[200]}$, and undertook systematic studies on the degradation mechanism, restoration theory, and biological and ecological technology of alkaline-saline grassland. Their studies showed that the secondary salinization of grassland soil is the main reason for the formation of alkaline-saline soil, induced by the vegetation degradation due to strong anthropogenic disturbance. It was suggested that to protect and recover vegetation is an effective way to prevent and improve alkaline-saline grassland soil ${ }^{[201]}$. Enclosing was shown to be an effective way for natural restoration, to promote vegetation succession and to restore to the original vegetation for the alkalinized grassland ${ }^{[202]}$. They suggested some biological, physical and chemical approaches to improve alkaline-saline grassland, setting up litter layer and sowing plants with high tolerance to alkali and salt, irrigation, plowing, coring sand and applying acidifying chemicals ${ }^{[203-205]}$. An ecological restoration and optimal models for development on alkaline meadow was conclusively proposed ${ }^{[206]}$. Vegetation succession was divided into five stages, and there were further studies on the dynamic population models, progressive succession, modular structures of populations, seed flows in plant communities and spatial patterns of plant diversity ${ }^{[207-211]}$.

The Qinghai-Tibetan Plateau, the highest and youngest plateau on earth, is one of the most important components of natural ecosystems and among the most threatened landscapes in the world. The alpine meadows are vital for water conservation and the productivity of local grasslands ${ }^{[212,213]}$. However, degraded grasslands account for $25 \%$ of the total area of this region representing about half of the total alpine grassland. The area has becomes bare land without vegetation in the cold season, which is followed by the land being covered with poisonous and ruderal plants that are inedible by livestock in the warm season. This leads not only to ecological problems but also greatly reduces the productivity of these grasslands $^{[214-216]}$. Degradation of black-soil grassland was caused by a complex set of factors such as altitude range, district characteristics and weather conditions, which have existed for a long period of time. Livestock overgrazing and climate dryness were the dominant factors that led to the degradation of the grasslands in question. In addition, damage done by rodents, especially pikas (Ochotona curzoniae), via burrowing through the turf and gnawing at herbs, have accelerated the process of degradation of black-soil grassland. Furthermore, with the increase in the population over the last 20 year, the influence of human activity on grassland degradation cannot be ignored. Based on the different successive stages of degradation of the black-soil grassland ecosystem, different restorative measures have been suggested. The light to moderately degraded grasslands should be protected from disturbance by strategies such as fencing, weeding, fertilizing, using rodenticide, decreasing stocking rate, optimizing livestock population structure and slaughter ages. From heavily to extremely degraded grasslands, artificial and semi-artificial grassland establishment is required to restore these ecosystems ${ }^{[217]}$.

\section{Grassland ecosystem health assess- ments}

Grassland ecosystem health assessment is one of the fastest growing branches of grassland ecology. The research on grassland health assessment focuses on the investigation of the standard, maintenance, restoration and regulatory mechanisms for grassland ecosystem health, and the establishment and development of health monitoring systems and management tools. This can lay the foundation for the theoretical system and methodology of grassland health assessment.

\subsection{The concept of grassland ecosystem health}

Ecosystem health is a term used to describe the condition of an ecosystem, and the health metaphor has been applied 
to the environment since the early $1800 \mathrm{~s}^{[218-220]}$. The term, ecosystem management, has been in use since the $1950 \mathrm{~s}^{[221]}$. The term, ecosystem health, has become widespread in the ecological literature, as a general metaphor meaning something beneficial ${ }^{[222]}$, and as an environmental quality goal in field assessments of rivers $^{[223]}$, lakes ${ }^{[224]}$, seas and forests ${ }^{[225]}$.

The concept of grassland ecosystem health was proposed in the 1930s to 1940 s, when human-dominated ecosystems became highly dysfunctional and degraded across the globe $\mathrm{e}^{[226]}$. The research in this area started in the early 1980s in China mainly to evaluate the comprehensive benefit of grassland ecosystem ${ }^{[227]}$. Productivity is the productive capacity or level of production at which the ecosystem keeps healthy. System health status is the trend that the basic structure and functioning of ecosystem could be improved, and the system could keep stable ${ }^{[228]}$. From a systematic point of view, it has been suggested that the health of grazing ecosystems is the health of the three subsystems of the soil, plants and animals. From the point of view of plants, this involves the physiological and ecological processes of community, population, and individuals. From the point of view of animal husbandry, it is the quality and quantity of plant production and animal production to be sustained and improved over time. It results from the coupling and overcoming of the system constraints under the control of human activities ${ }^{[229]}$. Others have suggested that grassland health is the extent to which the land, vegetation, water and air, and their ecological processes can be maintained in the grassland ecosystem ${ }^{[230]}$. The health of the grassland should include several main aspects: stability of soil and land, hydrological function, and integrity of biological communities. Therefore, the purpose of grassland ecosystem management is to ensure that grasslands are always in good health.

\subsection{Evaluation indexes and methods for grassland ecosystem health}

A key issue for grassland ecosystem health assessment is how to select effective evaluation indexes and establish appropriate evaluation methods. Index systems have preliminarily been established in North America and Australia. There are 17 indexes for grassland evaluation in North America, and a method of landscape function analysis is adopted in Australia. Generally, the evaluation methods for grassland ecosystem health include methods for factor list, factor compound, functioning evaluation, and interface or key process ${ }^{[226]}$. For the method of factor list, there is the lack of quantitative relationships between indexes, but there is a strong pertinence, and it can be a simple, definite and quick indicator for system health if properly used. The method of functioning evaluation incorporates ecosystem function indicators into the evaluation system, including three stages: choice and calculation, determination of the weight and assembly composite of index. The method of interface or key process integrates the various attribution of the ecosystem by understanding the key ecosystem processes, integrating the various attributes of the ecosystem, and establishes the integrated indicators based on the interaction among the components. Although this issue has been given due consideration in China, there is little research in this field.

The establishment of an effective evaluation index system is essential for grassland ecosystem health assessment. Due to the complexity, temporal and spatial variability of grassland ecosystem, and the limitation of evaluation methods, the evaluation method for grassland health should be carefully selected and repeatedly verified $^{[231]}$. Firstly, the method should be chosen based on the basic attributes of the grassland ecosystem, especially the key variable of ecosystem processes and functioning. Secondly, the effectiveness, sensitivity and operability of alternative indicators should be considered $^{[230]}$. Meanwhile, the integration of grassland health assessment indicators should be given attention, because it is sensitive to environment stresses, can warn the risk of grassland degradation, and is associated with grassland functioning ${ }^{[232]}$. Ren et al. ${ }^{[233]}$ suggested that the condition (C) of grassland should be integrated into the VOR (vigor, organization, and resilience) index, and establish the CVOR (condition, vigor, organization, and resilience) index for grassland health evaluation from the interface between soil land and vegetation. The CVOR index was established as the key indicator of land condition and ecological processes to evaluate the health of Alashan grassland and it showed that the grassland health depended on the level of grassland management. The CVOR index was also established for a typical grassland and was effective for evaluating the health of this grassland ${ }^{[234]}$. Overall, CVOR is simple, accurate, practical and comprehensive.

\subsection{Grassland ecosystem health status}

The health of grassland ecosystems is dynamic, and relating to the health status, grassland may be degraded due to excessive human activities and natural stresses. Grassland degradation could be regarded as a process of health loss. Such processes are usually divided into three to five stages. Degraded grassland was divided into four stages, including light, moderate, severe, extreme degradation $^{[235]}$. Health status was divided into four states, including healthy, threatened, unhealthy and collapsed ${ }^{[236]}$. The stages are determined from a long investigation on the succession in a grassland ecosystem. The health stages should be objective to be suitable for the succession law of grassland, and be subjective to be convenient for management. Subjective assessments of health stages are limited by the recognition skills of the assessor and affected by the dynamics of human requirements for grassland functioning. 
With the analysis of grassland health and degradation, ecologists are not only concerned with change processes affecting grassland condition, but also with thresholds. Grassland ecosystems are sensitive to outside inputs at particular stages, and there are thresholds between stages ${ }^{[237]}$. The synergy between subsystems could also change and there are thresholds between them ${ }^{[236]}$. The threshold of ecosystem health refers to the status of that ecosystem when it vulnerable to collapse with disturbance that overwhelms its resilience ${ }^{[238]}$. The warning index of ecosystem health is a suitable beginning for classifying ecosystem health, but there is more research needed on the thresholds of grassland health.

\section{Conclusion remarks and future outlook}

Over the last three decades in China, there have been increasing research on and documentation of the main aspects of grassland ecology, revealing the improvement of classic ecology concepts and theories, and the applicability of ecological principles of grassland conservation or management. The profound contributions to ecology theory have been focusing on (1) the ecosystem functions of biodiversity (plant productivity, animal performance and soil nutrient pool $)^{[11,12,239]}$; and (2) the ecological stoichiometric mechanisms of grassland community stability ${ }^{[13]}$. Meanwhile, important progress in grassland conservation and management has been made in (1) mechanisms controlling locust outbreaks induced by livestock grazing ${ }^{[14,59,60]}$; and (2) grazing regulating plant population dynamics, plant diversity and nutrient cycling ${ }^{[46,48,52,80,82,107]}$. Additionally, some studies from experimental research have provided new insights into the effects of global climate change on grassland plant traits $^{[119,126,134]}$, insect communities ${ }^{[167,168]}$, soil fauna and microbial communities ${ }^{[155]}$, and systematical carbon and nutrient flux ${ }^{[143,144]}$.

In conclusion, significant advances in grassland ecology in China have been achieved by the concerted efforts of ecologists undertaking observational, experimental and theoretical studies ${ }^{[240]}$. Nevertheless, there are still important challenges for the grassland ecology research in China as followings:

(1) Future research needs to strength the basic ecological theory for grassland ecosystems because these ecosystems are more complex than previous thought. As one of grassland system dimensions is spatial processes, the analytical or assessment consequences for grassland properties and functions should be associated to spatial patterns or heterogeneity. Moreover, abovegroundbelowground linkages need to be given more attention due to increasing evidence demonstrating that interactions between aboveground and belowground communities regulate grassland functions.

(2) Grassland ecologists are aware that the impacts of large herbivores (livestock) are highly diverse and closely related to grassland multi-functionality. Thus, future research on grazing activity and its application needs to consider the systematical consequences from grassland structure to process, and to multiple functions, as well as livestock species or assemblages, which potentially improve adaptive management.

(3) The effects of climate change need to be investigated with more experimental research across the grassland belt from the meadow steppes in the north-east to alpine steppes of the Qinghai-Tibetan Plateau and Tian Mountain. Given that climate changes, such as warming, and altering precipitation or $\mathrm{N}$ deposition, will have long-term effects on the grassland processes and functions, there is need for continued efforts to examine and establish the underlying mechanisms.

(4) Ecological methods and experimental techniques have a vital role in grassland ecology. For example, the lack of credible sampling methods, such as plant root measurement, and nutrient or microbe sampling with highly heterogeneity soils, impedes the acquisition of accurate data so that reliable conclusions cannot be made.

Acknowledgements This project was supported by the National Natural Science Foundation of China (31770520, 31230012, 31700357), the National Key Research and Development Program of China (2016YFC0500602), and Program for Introducing Talents to Universities (B16011)

Compliance with ethics guidelines Deli Wang, Ling Wang, Jushan Liu, Hui Zhu, and Zhiwei Zhong declare they have no conflicts of interest or financial conflicts to disclose.

This article is a review and does not contain any studies with human or animal subjects performed by any of the authors.

\section{References}

1. Wang D L, Hou F J, Liang C Z, Zhu T C. Research on the grassland ecosystem. In: China Association for Science and Technology, eds. Development reports on ecology discipline. Beijing: China Science \& Technology Press, 2012 (in Chinese)

2. Zhu T. A primary analysis to the vegetation near Sartu, Heilongjiang Province. Acta Botanica Sinica, 1955, 4(2): 117135 (in Chinese)

3. Ma Y Q. A primary report on vegetation in the Inner Mongolian deserts. Journal of Inner Mongolia University, 1960, 1: 61-69 (in Chinese)

4. Zhu T C. The grasslands of the western of Northeast and the eastern of Inner Mongolia. In: Proceedings of the 1st Grassland Scientific Symposium of the Western of Northeast and the Eastern of Inner Mongolia. Changchun: Northeast Normal University Press, 1960 (in Chinese)

5. Zhang Z T. Effects of grazing on vegetation near water source in Hulunbeier grasslands. In: Proceedings of 1st Symposium on Grassland Science of Western Northeast China and Eastern InnerMongolia. Changchun: Jilin Normal University Press, 1960, 3748 (in Chinese) 
6. Li J T, Li B, Liu L Q, Fu J R. The vegetation of Shertara, Hulunbeir grassland, Inner Mongolia. Beijing: Science Press, 1986 (in Chinese)

7. Inner Mongolia Grassland Ecosystem Research Station. Research on grassland ecosystem. Beijing: Science Press, 1985 (in Chinese)

8. Inner Mongolia Grassland Ecosystem Research Station. Research on grassland ecosystem. Beijing: Science Press, 1988 (in Chinese)

9. Inner Mongolia Grassland Ecosystem Research Station. Research on grassland ecosystem. Beijing: Science Press, 1990 (in Chinese)

10. Liu J K, Wang Z W. Alpine meadow ecosystem. Beijing: Science Press, 1991 (in Chinese)

11. Bai Y, Han X, Wu J, Chen Z, Li L. Ecosystem stability and compensatory effects in the Inner Mongolia grassland. Nature, 2004, 431(7005): 181-184

12. Wang L, Wang D L, He Z B, Liu G F, Hodgkinson $\mathrm{K}$ C. Mechanisms linking plant species richness to foraging of a large herbivore. Journal of Applied Ecology, 2010, 47(4): 868-875

13. Yu Q, Chen Q, Elser J J, He N, Wu H, Zhang G, Wu J, Bai Y, Han $\mathrm{X}$. Linking stoichiometric homoeostasis with ecosystem structure, functioning and stability. Ecology Letters, 2010, 13(11): 13901399

14. Zhong Z, Li X, Pearson D, Wang D, Sanders D, Zhu Y, Wang L. Ecosystem engineering strengthens bottom-up and weakens topdown effects via trait-mediated indirect interactions. Proceedings of Royal Society: Biological Science, 2017, 284(1863): 20170894

15. Yang C W, Guo W Q, Shi D C. Physiological roles of organic acids in alkali-tolerance of the alkali-tolerant halophyte. Agronomy Journal, 2010, 102(4): 1081-1089

16. Liu J, Zhou Y, Luo C, Xiang Y, An L. De novo transcriptome sequencing of desert herbaceous Achnatherum splendens (Achnatherum) seedlings and identification of salt tolerance genes. Genes, 2016, 7(4): 12

17. Wang S M, Zhang J L, Flowers T J. Low-affinity $\mathrm{Na}^{+}$uptake in the halophyte Suaeda maritima. Plant Physiology, 2007, 145(2): 559571

18. Wang C M, Zhang J L, Liu X S, Li Z, Wu G Q, Cai J Y, Flowers T J, Wang S M. Puccinellia tenuiflora maintains a low $\mathrm{Na}^{+}$level under salinity by limiting unidirectional $\mathrm{Na}^{+}$influx resulting in a high selectivity for $\mathrm{K}^{+}$over $\mathrm{Na}^{+}$. Plant, Cell \& Environment, 2009, 32(5): 486-496

19. Yu C W, Murphy T M, Lin C H. Hydrogen peroxide-induced chilling tolerance in mung beans mediated through ABAindependent glutathione accumulation. Functional Plant Biology, 2003, 30(9): 955-963

20. Liu Y J, Zhao Z G, Si J, Di C X, Han J, An L Z. Brassinosteroids alleviate chilling-induced oxidative damage by enhancing antioxidant defense system in suspension cultured cells of Chorispora bungeana. Plant Growth Regulation, 2009, 59(3): 207-214

21. Zhao Z, Tan L, Dang C, Zhang H, Wu Q, An L. Deep-sequencing transcriptome analysis of chilling tolerance mechanisms of a subnival alpine plant, Chorispora bungeana. BMC Plant Biology, 2012, 12(1): 222

22. Xu Z, Zhou G. Responses of leaf stomatal density to water status and its relationship with photosynthesis in a grass. Journal of Experimental Botany, 2008, 59(12): 3317-3325
23. Xu Z, Zhou G, Shimizu H. Are plant growth and photosynthesis limited by pre-drought following rewatering in grass? Journal of Experimental Botany, 2009, 60(13): 3737-3749

24. Ma Q, Li Y X, Yuan H J, Hu J, Wei L, Bao A K, Zhang J L, Wang S M. ZxSOS1 is essential for long-distance transport and spatial distribution of $\mathrm{Na}^{+}$and $\mathrm{K}^{+}$in the xerophyte Zygophyllum xanthoxylum. Plant and Soil, 2014, 374(1-2): 661-676

25. Jiang J L, Su M, Chen Y R, Gao N, Jiao C J, Sun Z X, Li F M, Wang $\mathrm{C}$ Y. Correlation of drought resistance in grass pea (Lathyrus sativus) with reactive oxygen species scavenging and osmotic adjustment. Biologia, 2013, 68(2): 231-240

26. Zhong Z C, Zeng B. Research trends and advances on plant population ecology. Journal of Southwest Normal University, 2001, 26: 230-236 (in Chinese)

27. Yang Y F, Zhang B T. An analysis of seasonal variation of vegetative propagation and the relationships between biomass and population density of Aneurolepidium chinensis in Songnen plain of China. Acta Botanica Sinica, 1992, 34(2): 443-449 (in Chinese)

28. Yang Y F, Liu G C, Zhang B T. An analysis of age structure and the strategy for asexual propagation of Leymus chinensis population. Acta Botanica Sinica, 1995, 37(7): 147-153 (in Chinese)

29. Yang Y F, Li J D. Ecological plasticity of the quantitative characters per ear heads of Leymucs chinensis population in natural meadow in Northeast China. Acta Ecologica Sinica, 2001, 21(5): 752-758 (in Chinese)

30. Liu Z, Li X, Li R, Jiang D, Cao C. A comparative study on seed germination of 15 grass species in Keeqin Sandyland. Chinese Journal of Applied Ecology, 2003, 14(9): 1416-1420 (in Chinese)

31. Zhu Y J, Yang X J, Baskin C C, Baskin J M, Dong M, Huang Z Y. Effects of amount and frequency of precipitation and sand burial on seed germination, seedling emergence and survival of the dune grass Leymus secalinus in semiarid China. Plant and Soil, 2014, 374(1-2): 399-409

32. Gao R, Yang X, Yang F, Wei L, Huang Z, Walck J L. Aerial and soil seed banks enable populations of an annual species to cope with an unpredictable dune ecosystem. Annals of Botany, 2014, 114(2): 279-287

33. Liu H D, Yu F H, He W M, Chu Y, Dong M. Are clonal plants more tolerant to grazing than co-occurring non-clonal plants in inland dunes? Ecological Research, 2007, 22(3): 502-506

34. Liu H D, Yu F H, He W M, Chu Y, Dong M. Clonal integration improves compensatory growth in heavily grazed ramet populations of two inland-dune grasses. Flora, 2009, 204(4): 298-305

35. Li S L, Yu F H, Werger M J, Dong M, Zuidema P A. Habitatspecific demography across dune fixation stages in a semi-arid sandland: understanding the expansion, stabilization and decline of a dominant shrub. Journal of Ecology, 2011, 99(2): 610-620

36. He W M, Alpert P, Yu F H, Zhang L L, Dong M. Reciprocal and coincident patchiness of multiple resources differentially affect benefits of clonal integration in two perennial plants. Journal of Ecology, 2011, 99(5): 1202-1210

37. Bai Y, Wu J, Xing Q, Pan Q, Huang J, Yang D, Han X. Primary production and rain use efficiency across a precipitation gradient on the Mongolia Plateau. Ecology, 2008, 89(8): 2140-2153

38. Yang D L, Han G D, Hu Y G, Wu Y G L. Effects of grazing 
intensity on plant diversity and aboveground biomass of Stipa baicolensis grassland. Chinese Journal of Ecology, 2006, 25: 1470-1475 (in Chinese)

39. Yan R R, Xin X P, Yan Y C, Wang X, Zhang B H, Yang G C, Liu S $\mathrm{M}$, Deng Y, Li L H. Impacts of differing grazing rates on canopy structure and species composition in Hulunber Meadow Steppe. Rangeland Ecology and Management, 2015, 68(1): 54-64

40. Li W, Wu G L, Zhang G F, Du G Z. The maintenance of offspring diversity in response to land use: sexual and asexual recruitment in an alpine meadow on the Tibetan Plateau. Nordic Journal of Botany, 2011, 29(1): 81-86

41. Peng J T, Liang C Z, Niu Y M, Jiang W, Wang W, Wang L X. Moderate grazing promotes genetic diversity of Stipa species in the Inner Mongolian steppe. Landscape Ecology, 2015, 30(9): 17831794

42. Wan H W, Bai Y F, Hooper D U, Schönbach P, Gierus M, Schiborra A, Taube F. Selective grazing and seasonal precipitation play key roles in shaping plant community structure of semi-arid grasslands. Landscape Ecology, 2015, 30(9): 1767-1782

43. Lu X Y, Kelsey K C, Yan Y, Sun J, Wang X D, Cheng G W, Neff J C. Effects of grazing on ecosystem structure and function of alpine grasslands in Qinghai-Tibetan Plateau: a synthesis. Ecosphere, 2017, 8(1): e01656

44. Wilson P J, Thompson K, Hodgson J G. Specific leaf area and leaf dry matter content as alternative predictors of plant strategies. New Phytologist, 1999, 143(1): 155-162

45. Zheng S X, Ren H Y, Lan Z C, Li W H, Wang K B, Bai Y F. Effects of grazing on leaf traits and ecosystem functioning in Inner Mongolia grasslands: scaling from species to community. Biogeosciences, 2010, 7(3): 1117-1132

46. Niu K C, He J S, Lechowicz M J. Grazing-induced shifts in community functional composition and soil nutrient availability in Tibetan alpine meadows. Journal of Applied Ecology, 2016, 53(5): 1554-1564

47. Wang D L, Du J, Zhang B T, Ba L, Hodgkinson K C. Grazing intensity and phenotypic plasticity in the clonal grass Leymus chinensis. Rangeland Ecology and Management, 2017, 70(6): 740-747

48. Bai W, Fang Y, Zhou M, Xie T, Li L, Zhang W H. Heavily intensified grazing reduces root production in an Inner Mongolia temperate steppe. Agriculture, Ecosystems \& Environment, 2015, 200: $143-150$

49. Ma L, Guo C, Lü X, Yuan S, Wang R. Soil moisture and land use are major determinants of soil microbial community composition and biomass at a regional scale in northeastern China. Biogeosciences, 2015, 12(8): 2585-2596

50. Li Y, Lin Q, Wang S, Li X, Liu W, Luo C, Zhang Z, Zhu X, Jiang $\mathrm{L}$, Li X. Soil bacterial community responses to warming and grazing in a Tibetan alpine meadow. FEMS Microbiology Ecology, 2016, 92(1): fiv152

51. Qi Q, Zhao M, Wang S, Ma X, Wang Y, Gao Y, Lin Q, Li X, Gu B, Li G, Zhou J, Yang Y. The biogeographic pattern of microbial functional genes along an altitudinal gradient of the Tibetan Pasture. Frontiers in Microbiology, 2017, 8: 976

52. Yang Y, Wu L, Lin Q, Yuan M, Xu D, Yu H, Hu Y, Duan J, Li X, He Z, Xue K, van Nostrand J, Wang S, Zhou J. Responses of the functional structure of soil microbial community to livestock grazing in the Tibetan alpine grassland. Global Change Biology, 2013, 19(2): 637-648

53. Liu S L, Zhao H D, Su X K, Deng L, Dong S K, Zhang X. Spatiotemporal variability in rangeland conditions associated with climate change in the Altun Mountain National Nature Reserve on the Qinghai-Tibet Plateau over the past 15 years. Rangeland Journal, 2015, 37(1): 67-75

54. Hu J, Wu J H, Ma M J, Nielsen U N, Wang J, Du G Z. Nematode communities response to long-term grazing disturbance on Tibetan plateau. European Journal of Soil Biology, 2015, 69: 24-32

55. Kang L. Influence of livestock grazing on grasshopper (Orthoptera: Acrididae) diversity in the Inner Mongolian steppes. Chinese Biodiversity, 1994, 2: 9-17 (in Chinese)

56. Kang L. Grasshopper-plant interactions under different grazing intensities in Inner Mongolia. Acta Ecologica Sinica, 1995, 15: 111 (in Chinese)

57. Kang L, Chen Y L. Dynamics of grasshopper communites under different grazing intensities in Inner Mongolian steppes. Entomologia Sinica, 1995, 2: 265-281 (in Chinese)

58. Kang L, Zhang M Z. Grasshopper species-area relationship on ungrazed and overgrazed grasslands. Chinese Biodiversity, 1996, 4: 15-22 (in Chinese)

59. Cease A J, Elser J J, Ford C F, Hao S, Kang L, Harrison J F. Heavy livestock grazing promotes locust outbreaks by lowering plant nitrogen content. Science, 2012, 335(6067): 467-469

60. Zhong Z, Wang D, Zhu H, Wang L, Feng C, Wang Z. Positive interactions between large herbivores and grasshoppers, and their consequences for grassland plant diversity. Ecology, 2014, 95(4): $1055-1064$

61. Zhu H, Wang D L, Wang L, Bai Y G, Fang J, Liu J. The effects of large herbivore grazing on meadow steppe plant and insect diversity. Journal of Applied Ecology, 2012, 49(5): 1075-1083

62. Hao S G, Wang S P, Cease A, Kang L. Landscape level patterns of grasshopper communities in Inner Mongolia: interactive effects of livestock grazing and a precipitation gradient. Landscape Ecology, 2015, 30(9): 1657-1668

63. Zhu H, Qu Y K, Zhang D, Li J, Wen M, Wang D, Ren B, Li J J, Wen M, Wang D L, Ren B Z. Impacts of grazing intensity and increased precipitation on a grasshopper assemblage (Orthoptera: Acrididae) in a meadow steppe. Ecological Entomology, 2017, 42 (4): 458-468

64. Zhu H, Wang D L, Guo Q F, Liu J, Wang L. Interactive effects of large herbivores and plant diversity on insect abundance in a meadow steppe in China. Agriculture, Ecosystems \& Environment, 2015, 212: 245-252

65. Li W H, Zhan S X, Lan Z C, Wu X B, Bai Y F. Scale-dependent patterns and mechanisms of grazing-induced biodiversity loss: evidence from a field manipulation experiment in semiarid steppe. Landscape Ecology, 2015, 30(9): 1751-1765

66. Yao G Z, Gao Y, Yang T T, Ding Y, Ma S L. The influence of grazing intensities on litter storage and vegetation productivity of Stipa klemenzii desert steppe. Journal of Arid Land Resources and Environmen, 2016, 10: 93-97

67. Yan L, Zhou G, Zhang F. Effects of different grazing intensities on grassland production in China: a meta-analysis. PLoS One, 2013, 8 


\section{(12): e81466}

68. Xiong D, Shi P, Sun Y, Wu J, Zhang X. Effect of grazing exclusion on plant productivity and soil carbon, nitrogen storage in alpine meadows in Northern Tibet, China. Chinese Geographical Science, 2014, 24(4): 488-498 (in Chinese)

69. Yao A X, Wang P, Fan F C, Hu T M. Studies on primary productivity for swards of perennial ryegrass/white cover under different grazing treatments. Grassland of China, 1998, 2: 12-16 (in Chinese)

70. Wang L, Liu Z, Liu H, Wang W, Liang C, Qiao J. Ecosystem health assessment of typical steppe in Inner Mongolia. Acta Ecologica Sinica, 2008, 28: 544-550 (in Chinese)

71. Li Q F, Han G D, Wei Z J, Ao T G, Peng S L. Effect of rotational and continuous grazing system on vegetation in Stipa breviflora desert steppe. Research of Agricultural Modernization, 2002, 23 (3): 192-196 (in Chinese)

72. Xing Q, Shuang Q, Jin Y, Song M. Studies on matter dynamics and plant compensatory growth under different grazing system on meadow steppe. Grassland of China, 2004, 5: 26-31 (in Chinese)

73. Han G D, Jiao S Y, Bi L G T, Biligetu A. Effects of plant species diversity and productivity under different stocking rates in the Stipa breviflora Griseb. desert steppe. Acta Ecologica Sinica, 2007, 27(1): 182-188 (in Chinese)

74. Li C L, Hao X Y, Zhao M L, Han G D, Willms W D. Influence of historic sheep grazing on vegetation and soil properties of a Desert Steppe in Inner Mongolia. Agriculture, Ecosystems \& Environment, 2008, 128(1-2): 109-116

75. Liang Y, Han G D, Zhou H, Zhao M L, Snyman H A, Shan D, Havsta K M. Grazing intensity on vegetation dynamics of a typical steppe in Northeast Inner Mongolia. Rangeland Ecology and Management, 2009, 62(4): 328-336

76. Gross K L, Pregitzer K S, Burton A J. Spatial variation in nitrogen availability in three successional plant communities. Journal of Ecology, 1995, 83(3): 357-367

77. Schimel J P, Bennett J. Nitrogen mineralization: challenges of a changing paradigm. Ecology, 2004, 85(3): 591-602

78. Risch A C, Schütz M, Vandegehuchte M L, van der Putten W H, Duyts H, Raschein U, Gwiazdowicz D J, Busse M D, PageDumroese D S, Zimmermann S. Aboveground vertebrate and invertebrate herbivore impact on net $\mathrm{N}$ mineralization in subalpine grasslands. Ecology, 2015, 96(12): 3312-3322

79. Frank D A, Evans R D. Effects of native grazers on grassland N cycling in Yellowstone National Park. Ecology, 1997, 78(7): 22382248

80. Shan Y, Chen D, Guan X, Zheng S X, Chen H J, Wang M J, Bai Y F. Seasonally dependent impacts of grazing on soil nitrogen mineralization and linkages to ecosystem functioning in Inner Mongolia grassland. Soil Biology \& Biochemistry, 2011, 43(9): 1943-1954

81. Bai Y F, Wu J G, Clark C M, Pan Q M, Zhang L X, Chen S P, Wang Q B, Han X G. Grazing alters ecosystem functioning and C: $\mathrm{N}$ : P stoichiometry of grasslands along a regional precipitation gradient. Journal of Applied Ecology, 2012, 49(6): 1204-1215

82. Liu C, Wang L, Song X X, Chang Q, Frank D A, Wang D L, Li J, Lin H J, Du F Y. Towards a mechanistic understanding of the effect that different species of large grazers have on grassland soil $\mathrm{N}$ availability. Journal of Ecology, 2018, 106(1): 357-366

83. Dong X Y, Fu H, Li X D, Niu D C, Guo D, Li X D. Effects on plant biomass and CNP contents of plants in grazed and fenced steppe grasslands of the Loess Plateau. Acta Prataculturae Sinica, 2010, 19(2): 175-182 (in Chinese)

84. Wang S P, Wilkes A, Zhang Z C, Chang X F, Lang R, Wang Y F, Niu H S. Management and land use change effects on soil carbon in northern China's grasslands: a synthesis. Agriculture, Ecosystems \& Environment, 2011, 142(3-4): 329-340

85. Wang Y F, Chen Z Z, Tieszen L T. Distribution of soil organic carbon in the major grasslands of Xilinguole, Inner Mongolia, China. Acta Phytoecologica Sinica, 1998, 22(6): 545-551 (in Chinese)

86. Wei Z, Wu R, Dabu X, Su J A, Yang S. The influence of different grazing systems on soil physical and chemical properties in desert steppe. Grassland China, 2005, 6-10 (in Chinese)

87. Li C L, Hao X Y, Zhao M L, Han G D, Willms W D. Influence of historic sheep grazing on vegetation and soil properties of a desert steppe in Inner Mongolia. Agriculture, Ecosystems \& Environment, 2008, 128(1-2): 109-116

88. Gao Y H, Luo P, Wu N, Chen H, Wang G X. Grazing intensity impacts on carbon sequestration in an alpine meadow on the eastern Tibetan Plateau. Research Journal of Agriculture and Biological Sciences, 2007, 3(6): 642-647

89. Wang S, Wang Y, Chen Z. Management of Grazing Ecosystem. Beijing: Science Press, 2003.

90. Fan Y, Hou X, Shi H, Shi S. Effects of grazing and fencing on carbon and nitrogen reserves in plants and soils of alpine meadow in the three headwater resource regions. Russian Journal of Ecology, 2013, 44(1): 80-88

91. Sun D S, Wesche K, Chen D D, Zhang S H, Wu G L, Du G Z, Comerford N B. Grazing depresses soil carbon storage through changing plant biomass and composition in a Tibetan alpine meadow. Plant, Soil and Environment, 2011, 57(6): 271-278

92. Wang J, Sha L Q, Li J Z, Feng Z L. $\mathrm{CO}_{2}$ efflux under different grazing managements on subalpine meadows of Shangri-La, Northwest Yunnan Province, China. Acta Ecologica Sinica, 2008, 28(8): 3574-3583 (in Chinese)

93. Zou J, Zhao L, Xu S, Xu X, Chen D, Li Q, Zhao N, Luo C, Zhao X. Field ${ }^{13} \mathrm{CO}_{2}$ pulse labeling reveals differential partitioning patterns of photo assimilated carbon in response to livestock exclosure in a Kobresia meadow. Biogeosciences, 2014, 11(16): 4381-4391

94. Wang X D, Yan Y, Cao Y Z. Impact of historic grazing on steppe soils on the northern Tibetan Plateau. Plant and Soil, 2012, 354(12): 173-183

95. Liu N, Kan H M, Yang G W, Zhang Y J. Changes in plant, soil, and microbes in a typical steppe from simulated grazing: explaining potential change in soil C. Ecological Monographs, 2015, 85(2): 269-286

96. Hodgson J G, Illius A W. The ecology and management of grazing systems. Wallingford: CAB International, 1996

97. Liu J X, Hu Z Z, Ren J Z, Liang X, Su W J. The serial studies of ecological grazing and digestion and metabolism of sheep on alpine pasture:I. The study of forage preference index of grazing sheep. Acta Prataculturae Sinca, 1997, 8: 31-34 (in Chinese)

98. Wang S P, Li Y H. Behavior ecology of grazing sheep: V. 
interrelation between ingestion behavior and sward characteristics. Acta Prataculturae Sinca, 1997, 6: 31-38 (in Chinese)

99. Wang M J, Wan X R, Zhong W Q. The interaction between the vegetarian and the plant. Chinese Journal of Ecology, 2001, 20(5): 39-43 (in Chinese)

100. Wang L, Wang D L, Bai Y G, Jiang G T, Liu J S, Huang Y, Li Y X. Spatial distributions of multiple plant species affect herbivore foraging selectivity. Oikos, 2010, 119(2): 401-408

101. Wang L, Wang D, Bai Y, Huang Y, Fan M, Liu J, Li Y. Spatially complex neighboring relationships among grassland plant species as an effective mechanism of defense against herbivory. Oecologia, 2010, 164(1): 193-200

102. Wang L, Wang D L, Liu J S, Huang Y, Hodgkinson K C. Diet selection variation of a large herbivore in a feeding experiment with increasing species numbers and different plant functional group combinations. Acta Oecologica, 2011, 37(3): 263-268

103. Han G D, Hao X Y, Zhao M L, Wang M J, Ellert B H, Willms W, Wang M J. Effect of grazing intensity on carbon and nitrogen in soil and vegetation in a meadow steppe in Inner Mongolia. Agriculture, Ecosystems \& Environment, 2008, 125(1-4): 21-32

104. Gao Y Z, Giese M, Lin S, Sattelmacher B, Zhao Y, Brueck H. Belowground net primary productivity and biomass allocation of a grassland in Inner Mongolia is affected by grazing intensity. Plant and Soil, 2008, 307(1-2): 41-50

105. Xiao X P, Song N P, Wang X, Yang M X, Xie T T. Effects of grazing disturbance to soil and vegetation of desert grassland. Soil and Water Conservation, 2013, 12: 19-33 (in Chinese)

106. Shi X M, Li X G, Li C T, Zhao Y, Shang Z H, Ma Q. Grazing exclusion decreases soil organic $\mathrm{C}$ storage at an alpine grassland of the Qinghai-Tibetan Plateau. Ecological Engineering, 2013, 57: 183-187

107. Zhou G, Zhou X, He Y, Shao J, Hu Z, Liu R, Zhou H, Hosseinibai S. Grazing intensity significantly affects belowground carbon and nitrogen cycling in grassland ecosystems: a meta-analysis. Global Change Biology, 2017, 23(3): 1167-1179

108. Laca E A, Sokolow S, Galli J R, Cangiano C A. Allometry and spatial scales of foraging in mammalian herbivores. Ecology Letters, 2010, 13(3): 311-320

109. Socher S A, Prati D, Boch S, Müller J, Baumbach H, Gockel S, Hemp A, Schöning I, Wells K, Buscot F, Kalko E K V, Linsenmair K E, Schulze E D, Weisser W W, Fischer M. Interacting effects of fertilization, mowing and grazing on plant species diversity of 1500 grasslands in Germany differ between regions. Basic and Applied Ecology, 2013, 14(2): 126-136

110. van der Plas F, Howison R A, Mpanza N, Cromsigt J P G M, Olff H. Different-sized grazers have distinctive effects on plant functional composition of an African savannah. Journal of Ecology, 2016, 104(3): 864-875

111. Charles G K, Porensky L M, Riginos C, Veblen K E, Young T P. Herbivore effects on productivity vary by guild: cattle increase mean productivity while wildlife reduce variability. Ecological Applications, 2017, 27(1): 143-155

112. Arsenault R, Owen-Smith N. Facilitation versus competition in grazing herbivore assemblages. Oikos, 2002, 97(3): 313-318

113. van Klink R, Noltea S, Mandemaa F S, Lagendijk D D G, WallisDeVriese M F, Bakker J P, Esselink P, Smita C. Effects of grazing management on biodiversity across trophic levels-The importance of livestock species and stocking density in salt marshes. Agriculture, Ecosystems \& Environment, 2016, 235: 329339

114. Eldridge D J, Poore A G B, Ruiz-Colmenero M, Letnic M, Soliveres S. Ecosystem structure, function, and composition in rangelands are negatively affected by livestock grazing. Ecological Applications, 2016, 26(4): 1273-1283

115. Liu J, Feng C, Wang D L, Wang L, Wilsey B J, Zhong Z W. Impacts of grazing by different large herbivores in grassland depend on plant species diversity. Journal of Applied Ecology, 2015, 52(4): 1053-1062

116. Liu C, Song X X, Wang L, Wang D L, Zhou X M, Liu J, Zhao X, Li J, Lin H J. Effects of grazing on soil nitrogen spatial heterogeneity depend on herbivore assemblage and pre-grazing plant diversity. Journal of Applied Ecology, 2016, 53(1): 242-250

117. Parmesan C. Ecological and evolutionary responses to recent climate change. Annual Review of Ecology Evolution and Systematics, 2006, 37(1): 637-669

118. Niu S L, Li Z X, Xia J Y, Han Y, Wu M Y, Wan S Q. Climatic warming changes plant photosynthesis and its temperature dependence in a temperate steppe of northern China. Environmental and Experimental Botany, 2008, 63(1-3): 91-101

119. Wan S, Xia J, Liu W, Niu S. Photosynthetic overcompensation under nocturnal warming enhances grassland carbon sequestration. Ecology, 2009, 90(10): 2700-2710

120. Chi Y, Xu M, Shen R, Yang Q, Huang B, Wan S. Acclimation of foliar respiration and photosynthesis in response to experimental warming in a temperate steppe in northern China. PLoS One, 2013, 8(2): e56482

121. Liu Y, Mu J, Niklas K J, Li G, Sun S. Global warming reduces plant reproductive output for temperate multi-inflorescence species on the Tibetan plateau. New Phytologist, 2012, 195(2): 427-436

122. Xia J, Wan S. Independent effects of warming and nitrogen addition on plant phenology in the Inner Mongolian steppe. Annals of Botany, 2013, 111(6): 1207-1217

123. Yang H J, Li Y, Wu M Y, Zhang Z, Li L H, Wan S Q. Plant community responses to nitrogen addition and increased precipitation: the importance of water availability and species traits. Global Change Biology, 2011, 17(9): 2936-2944

124. Niu S L, Wan S Q. Warming changes plant competitive hierarchy in a temperate steppe in northern China. Journal of Plant Ecology, 2008, 1(2): 103-110

125. Jiang L, Wan S Q, Li L H. Species diversity and productivity: why do results of diversity-manipulation experiments differ from natural patterns? Journal of Ecology, 2009, 97(4): 603-608

126. Yang H J, Wu M Y, Liu W X, Zhang Z, Zhang N L, Wan S Q. Community structure and composition in response to climate change in a temperate steppe. Global Change Biology, 2011, 17(1): 452-465

127. Niu K C, Choler P, de Bello F, Mirotchnick N, Du G Z, Sun S C. Fertilization decreases species diversity but increases functional diversity: a three-year experimental in a Tibetan alpine meadow. Agriculture, Ecosystems \& Environment, 2014, 182: 106-112

128. Xu Y F, Yi X C M, Fu J J, Chen H, Miao Y J, Chen J, Hu T M, Shan J G. Response of plant diversity and soil nutrient to grazing 
intensity in Kobresia pygmaea meadow of Qinghai-Tibet Plateau. Acta Agrestia Sinica, 2012, 6: 1026-1032 (in Chinese)

129. Tian Q, Liu N, Bai W, Li L, Chen J, Reich P B, Yu Q, Guo D, Smith M D, Knapp A K, Cheng W, Lu P, Gao Y, Yang A, Wang T, Li X, Wang Z, Ma Y, Han X, Zhang W H. A novel soil manganese mechanism drives plant species loss with increased nitrogen deposition in a temperate steppe. Ecology, 2016, 97(1): 65-74

130. Zhang Y, Lü X, Isbell F, Stevens C, Han X, He N, Zhang G, Yu Q, Huang J, Han X. Rapid plant species loss at high rates and at low frequency of $\mathrm{N}$ addition in temperate steppe. Global Change Biology, 2014, 20(11): 3520-3529

131. Bai W M, Wang Z W, Chen Q S, Zhang W H, Li L H. Spatial and temporal effects of nitrogen addition on root life span of Leymus chinensis in a typical steppe of Inner Mongolia. Functional Ecology, 2008, 22(4): 583-591

132. Wan S Q, Hui D F, Wallace L, Luo Y Q. Direct and indirect effects of experimental warming on ecosystem carbon processes in a tallgrass prairie. Global Biogeochemical Cycles, 2005, 19(2): GB2014

133. Ma W, Liu Z, Wang Z, Wang W, Liang C, Tang Y, He J S, Fang J. Climate change alters interannual variation of grassland aboveground productivity: evidence from a 22-year measurement series in the Inner Mongolian grassland. Journal of Plant Research, 2010, 123(4): 509-517

134. Lin D, Xia J, Wan S. Climate warming and biomass accumulation of terrestrial plants: a meta-analysis. New Phytologist, 2010, 188 (1): 187-198

135. Bai W M, Wan S Q, Niu S L, Liu W X, Chen Q S, Wang Q B, Zhang $\mathrm{W} \mathrm{H}$, Han $\mathrm{X} \mathrm{G}$, Li L H. Increased temperature and precipitation interact to affect root production, mortality, and turnover in a temperate steppe: implications for ecosystem $\mathrm{C}$ cycling. Global Change Biology, 2010, 16(4): 1306-1316

136. Zhou L, Dickinson R E, Tian Y, Vose R S, Dai Y. Impact of vegetation removal and soil aridation on diurnal temperature range in a semiarid region: application to the Sahel. Proceedings of the National Academy of Sciences of the United States of America, 2007, 104(46): 17937-17942

137. Bai W M, Xia J Y, Wan S Q, Zhang W H, Li L H. Day and night warming have different effect on root lifespan. Biogeosciences, 2012, 9(1): 375-384

138. Xu Z, Ren H, Cai J, Wang R, Li M H, Wan S, Han X, Lewis B J, Jiang Y. Effects of experimentally-enhanced precipitation and nitrogen on resistance, recovery and resilience of a semi-arid grassland after drought. Oecologia, 2014, 176(4): 1187-1197

139. Xu Z W, Ren H Y, Li M H, van Ruijven J, Han X G, Wan S Q, Li $\mathrm{H}$, Yu Q, Jiang Y, Jiang L. Environmental changes drive the temporal stability of semi-arid natural grasslands through altering species asynchrony. Journal of Ecology, 2015, 103(5): 1308-1316

140. Zhang Y, Loreau M, Lü X, He N, Zhang G, Han X. Nitrogen enrichment weakens ecosystem stability through decreased species asynchrony and population stability in a temperate grassland. Global Change Biology, 2016, 22(4): 1445-1455

141. Yang Z, Zhang Q, Su F, Zhang C, Pu Z, Xia J, Wan S, Jiang L. Daytime warming lowers community temporal stability by reducing the abundance of dominant, stable species. Global Change Biology, 2017, 23(1): 154-163
142. Yang H, Jiang L, Li L, Li A, Wu M, Wan S. Diversity-dependent stability under mowing and nutrient addition: evidence from a 7year grassland experiment. Ecology Letters, 2012, 15(6): 619-626

143. Xu W H, Wan S Q. Water- and plant-mediated responses of soil respiration to topography, fire, and nitrogen fertilization in a semiarid grassland in northern China. Soil Biology \& Biochemistry, 2008, 40(3): 679-687

144. Xia J Y, Chen J Q, Piao S L, Ciais P, Luo Y Q, Wan S Q. Terrestrial carbon cycle affected by non-uniform climate warming. Nature Geoscience, 2014, 7(3): 173-180

145. Xia J Q, Han Y, Zhang Z, Zhang Z, Wan S Q. Effects of diurnal warming on soil respiration are not equal to the summed effects of day and night warming in a temperate steppe. Biogeosciences, 2009, 6(8): 1361-1370

146. Liu L, Wang X, Lajeunesse M J, Miao G, Piao S, Wan S, Wu Y, Wang Z, Yang S, Li P, Deng M. A cross-biome synthesis of soil respiration and its determinants under simulated precipitation changes. Global Change Biology, 2016, 22(4): 1394-1405

147. Zhu C, Ma Y, Wu H, Sun T, La Pierre K J, Sun Z, Yu Q. Divergent effects of nitrogen addition on soil respiration in a semiarid grassland. Scientific Reports, 2016, 6(1): 33541

148. Lü X T, Han X G. Nutrient resorption responses to water and nitrogen amendment in semi-arid grassland of Inner Mongolia, China. Plant and Soil, 2010, 327(1-2): 481-491

149. Lü X T, Reed S, Yu Q, He N P, Wang Z W, Han X G. Convergent responses of nitrogen and phosphorus resorption to nitrogen inputs in a semiarid grassland. Global Change Biology, 2013, 19(9): 2775-2784

150. Wang C, Wang X, Liu D, Wu H, Lü X, Fang Y, Cheng W, Luo W, Jiang P, Shi J, Yin H, Zhou J, Han X, Bai E. Aridity threshold in controlling ecosystem nitrogen cycling in arid and semi-arid grasslands. Nature Communications, 2014, 5: 4799

151. Shi Y H, Zhou G S, Jiang Y L, Wang H, Xu Z Z. Does precipitation mediate the effects of elevated $\mathrm{CO}_{2}$ on plant growth in the grass species Stipa grandis? Environmental and Experimental Botany, 2016, 131: 146-154

152. Jiang $\mathrm{Y}, \mathrm{Xu} \mathrm{Z}$, Zhou G, Liu T. Elevated $\mathrm{CO}_{2}$ can modify the response to a water status gradient in a steppe grass: from cell organelles to photosynthetic capacity to plant growth. BMC Plant Biology, 2016, 16(1): 157

153. van der Heijden M G A, Bardgett R D, van Straalen N M. The unseen majority: soil microbes as drivers of plant diversity and productivity in terrestrial ecosystems. Ecology Letters, 2008, 11 (3): 296-310

154. Zhang N L, Xia J Y, Yu X J, Ma K P, Wan S Q. Soil microbial community changes and their linkages with ecosystem carbon exchange under asymmetrically diurnal warming. Soil Biology \& Biochemistry, 2011, 43(10): 2053-2059

155. Zhang N, Liu W, Yang H, Yu X, Gutknecht J L M, Zhang Z, Wan $\mathrm{S}$, Ma K. Soil microbial responses to warming and increased precipitation and their implications for ecosystem C cycling. Oecologia, 2013, 173(3): 1125-1142

156. Zhang N L, Wan S Q, Guo J X, Han G D, Gutknecht J, Schmid B, Yu L, Liu W X, Bi J, Wang Z, Ma K P. Precipitation modifies the effects of warming and nitrogen on soil microbial communities in northern Chinese grasslands. Soil Biology \& Biochemistry, 2015, 
89: $12-23$

157. Kim Y C, Gao C, Zheng Y, He X H, Yang W, Chen L, Wan S Q, Guo L D. Arbuscular mycorrhizal fungal community response to warming and nitrogen addition in a semiarid steppe ecosystem. Mycorrhiza, 2015, 25(4): 267-276

158. Chen Y L, Zhang X, Ye J S, Han H Y, Wan S Q, Chen B D. Sixyear fertilization modifies the biodiversity of arbuscular mycorrhizal fungi in a temperate steppe in Inner Mongolia. Soil Biology \& Biochemistry, 2014, 69: 371-381

159. Bardgett R D, van der Putten W H. Belowground biodiversity and ecosystem functioning. Nature, 2014, 515(7528): 505-511

160. Wu T J, Su F L, Han H Y, Du Y, Yu C D, Wan S Q. Responses of soil microarthropods to warming and increased precipitation in a semiarid temperate steppe. Applied Soil Ecology, 2014, 84: 200207

161. Song M, Jing S S, Zhou Y Q, Hui Y, Zhu L L, Wang F, Hui D F, Jiang L, Wan S Q. Dynamics of soil nematode communities in wheat fields under different nitrogen management in northern China plain. European Journal of Soil Biology, 2015, 71: 13-20

162. Song M, Li X M, Jing S S, Lei L J, Wang J L, Wan S Q. Responses of soil nematodes to water and nitrogen additions in an old-field grassland. Applied Soil Ecology, 2016, 102: 53-60

163. Guo K, Hao S G, Sun O J, Kang L. Differential responses to warming and increased precipitation among three contrasting grasshopper species. Global Change Biology, 2009, 15(10): 25392548

164. Liu Y, Reich P B, Li G, Sun S. Shifting phenology and abundance under experimental warming alters trophic relationships and plant reproductive capacity. Ecology, 2011, 92(6): 1201-1207

165. Xi X, Li D, Peng Y, Eisenhauer N, Sun S. Experimental warming and precipitation interactively modulate the mortality rate and timing of spring emergence of a gallmaking Tephritid fly. Scientific Reports, 2016, 6(1): 32284

166. Xi X Q, Wu X W, Nylin S, Sun S C. Body size response to warming: time of the season matters in tephritid fly. Oikos, 2016, 125(3): 386-394

167. Zhu H, Zou X, Wang D, Wan S, Wang L, Guo J. Responses of community-level plant-insect interactions to climate warming in a meadow steppe. Scientific Reports, 2015, 5(1): 18654

168. Zhu H, Wang D L, Wang L, Fang J, Sun W, Ren B Z. Effects of altered precipitation on insect community composition and structure in a meadow steppe. Ecological Entomology, 2014, 39 (4): 453-461

169. Wang W, Liu Z, Hao D, Liang C. Research on degenerated analysis the restoring succession of the grassland in Innermongolia II. Analysis of the restoring processes. Acta Phytoecologica Sinica, 1996a, 20: 460-471 (in Chinese)

170. Wang W, Liu Z L, Hao D Y, Liang C Z. The dynamic respond of degenerative steppe vegetation into grazing prohibited in the Inner Mongolia. Climatic and Environmental Ressarch, 1997, 2: 236240

171. Liu Z L, Wang W, Liang C Z, Hao D Y. The regressive succession pattern and its diagnostic of Inner Mongolia steppe in sustained and superstrong grazing. Acta Agrestia Sinica, 1998, 6: 244-251 (in Chinese)

172. Wang W, Liu Z L, Hao D Y, Liang C Z. Research on the restoring succession of the degenerated grassland in Innermongolia I. Basic characteristics and driving force for restoration of the degenerated grassland. Acta Phytoecologica Sinica, 1996, 20: 449-459 (in Chinese)

173. Hao D Y, Liu Z L, Wang W, Liang C Z. Research on the restoring succession of the degenerated grassland in inner Mongolia III. A mathematical model for plant community succession. Acta Phytoecologica Sinica, 1997, 21: 503-511 (in Chinese)

174. Zhao H L, Okuro T, Li Y L, Zuo X A, Zhou R L. Changes of plant community in grazing and restoration processes in Horqin sand land, Inner Mongolia. Journal of Desert Research, 2009, 29: 229235

175. Zhang J Y, Zhao H L. Spatial patterns of main species of the grassland community in the recovering succession in Horqin sandy land. Chinese Journal of Ecology, 2004, 23(2): 1-6 (in Chinese)

176. Zhou Z, Fu H, Chen Y, Wu C, Li X, Zhu X, Gan H, Ai D. Changes of the species diversity and productivity of Alashan steppe area in restoration succession. Acta Prataculturae Sinca, 2003, 12(1): 3440 (in Chinese)

177. Xin X P, Xu B, Wang X S, Yang Z Y, Guo Q. Dynamic analysis on spatial pattern of an alkaline grassland inrestoration succession. Acta Ecologica Sinica, 2001, 21(6): 877-882 (in Chinese)

178. Zhao Y Y, Hu X M. Review on mechanism of succession of degenerating meadow community during resuming process in Loess Plateau. Research of Soil and Water Conservation, 2008, 15: 270-272 (in Chinese)

179. Li H, Yang Y. [Effect of restorative measures on quantitative characters of reproduction for Leynrus chinensis population in the degenerated grassland]. Journal of Applied Ecology Sinica, 2004, 15(5): 819-823 (in Chinese)

180. Zhang J, Zhao $\mathrm{H}$. An case study on vegetation stability in sandy desertification land: Determination and comparison of the resilience among communities after a short period of extremely aridity disturbance. Acta Ecologica Sinica, 2011, 31(20): 60606071 (in Chinese)

181. Cheng J M, Jing Z B, Jin J W, Gao Y. Restoration and utilization mechanism of degraded grassland in the semi-arid region of Loess Plateau. Scientia Sinica Vitae, 2014, 44(3): 267-279 (in Chinese)

182. Sala O E, Paruelo J M. Ecosystem services in grasslands. Washington: Island Press, 1997

183. Wu J G. Landscape sustainability science: ecosystem services and human well-being in changing landscapes. Landscape Ecology, 2013, 28(6): 999-1023

184. Butchart S H M, Walpole M, Collen B, van Strien A, Scharlemann J P W, Almond R E A, Baillie J E M, Bomhard B, Brown C, Bruno J, Carpenter K E, Carr G M, Chanson J, Chenery A M, Csirke J, Davidson N C, Dentener F, Foster M, Galli A, Galloway J N, Genovesi P, Gregory R D, Hockings M, Kapos V, Lamarque J F, Leverington F, Loh J, McGeoch M A, McRae L, Minasyan A, Morcillo M H, Oldfield T E E, Pauly D, Quader S, Revenga C, Sauer J R, Skolnik B, Spear D, Stanwell-Smith D, Stuart S N, Symes A, Tierney M, Tyrrell T D, Vie J C, Watson R. Global biodiversity: indicators of recent declines. Science, 2010, 328 (5982): 1164-1168

185. Wade M R, Gurr G M, Wratten S D. Ecological restoration of farmland: progress and prospects. Philosophical Transactions of 
the Royal Society B: Biological Sciences, 2008, 363(1492): 831847

186. Li J D, Zheng Y. Studies on improving saline-alkaline grassland in Songnen plain. Journal of Northeast Normal University, 1995: 110-115 (in Chinese)

187. Chuan G, Nan Y, Zhang S, Ya T, Kou Z, Jiang D, Gu T, Gao T. The change of vegetation and soil in desertification grassland. Scientific and Technological Information of Soil and Water Conservation, 2000, 35: 16-20 (in Chinese)

188. Li Y, Zhao H, Zhao X. Soil respiration, carbon balance and carbon storage of sandy grassland under post-grazing natural restoration. Acta Prataculturae Sinica, 2006, 15(5): 25 (in Chinese)

189. Huang Y, An S, Xue H. Responses of soil microbial biomass $\mathrm{C}$ and $\mathrm{N}$ and respiratory quotient $\left(\mathrm{qCO}_{2}\right)$ to revegetation on the Loess Hilly-Gully region. Acta Ecologica Sinica, 2009, 29: 2811-2818 (in Chinese)

190. Zhang J, Li Y, Zhao X, Zhang T, She Q, Liu M, Wei S. Effects of exclosure on soil physicochemical properties and carbon sequestration potential recovery of desertified grassland. Journal of Desert Research, 2017, 37: 491-499

191. Li X Y, Dong S K, Zhu L, Wen L. Net carbon dioxide exchange of plant communities on degraded and restored alpine grasslands in headwater area of Three Rivers in China. Chinese Journal of Ecology Sinica, 2010, 29: 1940-1949 (in Chinese)

192. Yan Z, Zhao X, Yang F, Zeng Z, Liu Y, Liu F. Effect of restoration interference techniques on vegetation and soil carbon discharge of saline-alkali grassland. Territory and Natural Resources Study, 2014: 55-58 (in Chinese)

193. Shui W, Bai J, Jian X, Qi X H, Su Z, Chen Y, Cai Y. Changes in water conservation and soil physicochemical properties during the recovery of desertified grassland in Zoigê, China. Acta Ecologica Sinica, 2017, 37: 277-285 (in Chinese)

194. Shao Y Q, Zhao J, Yang J. Distribution characteristics of soil microbial numbers in recovered grassland and degenerated grassland. Journal of Desert Research, 2004, 24(2): 223-226 (in Chinese)

195. Wu D H, Yin W Y, Yang Z. Difference in soil mite community characteristics among different vegetation restoration practices in the moderatly degraded pasture of Songnen grassland. Acta Zoologica Sinica, 2007, 4: 607-615 (in Chinese)

196. Wu D H, Yin W Y, Bu Z. Changes among soil nematode community characteristics in relation to different vegetation restoration practices in themoderate degraded grasslands of Songnen. Acta Ecologica Sinica, 2008, 28: 1-12 (in Chinese)

197. Wu D H, Yin W Y, Yin X Q. Comparisons among soil collembola community characteristics in relation to different vegetation restoration treatments in the moderate degraded grasslands in the Songnen Plain of Northeast China. Acta Entomologica Sinica, 2008, 51: 11-15 (in Chinese)

198. Liu R, Zhao H. Changes in functional groups of soil macro-faunal community in degraded sandy grassland under post-grazing natural restoration in Hoqin Sand Land. Ecology and Environmental Sciences, 2011, 20: 1794-1798

199. SER. The SER Primer on Ecological Restoration, Version 2. Society for Ecological Restoration Science and Policy Working Group, 2004
200. Zhu T C. Preliminary analysis of vegetation near Saertu, Heilongjiang. Journal of Integrative Plant Biology, 1955, 4: 117-135 (in Chinese)

201. Zhang W Z. Secondary salinization of grassland soil-The formation of secondary saline-alkaline soil patches in grasslands of Songnen plain. Acta Pedologica Sinaca, 1993, 30: 182-190 (in Chinese)

202. Guo J X, Li J D, Zhang B T. Natural restoration of saline alkali grassland in Western Jilin Province. Agriculture and Technology, 1994b, 15: 27-30 (in Chinese)

203. Guo J X, Li J D, Zhang B T. Biological treatment of saline alkali grassland. Agriculture and Technology, 1994, 24: 35-38 (in Chinese)

204. Guo J X, Zhang B T, Wen M. Improvement of physical and chemical methods of saline alkali grassland. Agriculture and Technology, 1994, 25: 9-11 (in Chinese)

205. Guo J X, Zhang W, Xiao H. Vegetation degradation and soil salinization in Leymus chinensis grassland. Agriculture and Technology, 1994, 25: 39-42 (in Chinese)

206. Li J D, Zheng Y. Ecological restoration and optimal models for development on alkaline meadow in the Songnen plain of China. Journal of Northeast Normal University, 1995, 11: 67-71 (in Chinese)

207. Wang R Z, Li J D. Cluster analysis method for dividing successional stage of Aneuolepidium chinense grassland for grazing. Acta Ecologica Sinica, 1991, 11: 367-371 (in Chinese)

208. Wang R Z, Li J D. Dynamic population models of the ecological dominance during the deterioration of Leymus chinensis grassland. Acta Phytoecologica Sinica, 1995, 19: 170-174 (in Chinese)

209. Yang Y F, Zheng H Y. Comparison analysis on the experimental communities during progressive succession on alkaline patches in the songnen plain of China. Acta Phytoecologica Sinica, 1998, 22 (3): 214-221 (in Chinese)

210. Fan G, Li H, Yang Y. Analyse of the modular structures of populations on Leymus chinensis and Hierochloe glabra in different succession series in cutting grassland. Pratacultural Science, 2006, 23: 34-37 (in Chinese)

211. Han D Y, Yang Y X, Yang Y F, Li J D, Yang Y. Spatial patterns of plant species diversity in a degraded successional series of fragmented Leymus chinensis meadow in Songnen Plain of Northeast China. Journal of Applied Ecology Sinica, 2012, 23 (3): 666-672 (in Chinese)

212. Wang C T, Long R J, Wang Q J, Ding L M, Wang M P. Effects of altitude on plant-species diversity and productivity in an alpine meadow, Qinghai-Tibetan plateau. Australian Journal of Botany, 2007, 55(2): 110-117

213. Feng R, Long R, Shang Z, Ma Y, Dong S, Wang Y. Establishment of Elymus natans improves soil quality of a heavily degraded alpine meadow in Qinghai-Tibetan Plateau, China. Plant and Soil, 2010, 327(1-2): 403-411

214. Ma Y S, Lang B N. Establishing pratacultural system-A strategy for rehabilitation of "Black Soil" on the Tibetan Plateau. Pratacultural Science, 1998, 15(1): 5-9 (in Chinese)

215. Ma Y S, Li Q Y. Study on the control of weeds and poisonous plant on black soil type deteriorated alpine meadow. Pratacultural Science, 1999, 16(3): 46-50 (in Chinese) 
216. Ma Y S, Lang B N, Li Q Y, Shi J J, Dong Q M. Study on rehabilitating and rebuilding technologies for degenerated alpine meadow in the Changjiang and Yellow river source region. Pratacultural Science, 2001, 19(9): 1-5 (in Chinese)

217. Dong Q M, Zhao X Q, Wu G L, Shi J J, Ren G H. A review of formation mechanism and restoration measures of "black-soiltype" degraded grassland in the Qinghai-Tibetan Plateau. Environmental Earth Sciences, 2013, 70(5): 2359-2370

218. Anon.On the culture of potatoes. Framer's Magazine, 1839, 2: 337-338

219. Anon.Rural economy, agriculture, and husbandry. Encyclopaedia Perthensis, 1816, 19: 391-497

220. Rapport D. Defining ecosystem health. In Rapport D, eds, Ecosystem Health. Blackwell Scientific, 1998, 18-33

221. Lutz H J. Applications of ecology in forest management. Ecology, 1957, 38: 46-64

222. Jax K. Ecosystem Functioning. Oxford: Cambridge University Press, 2010

223. Davies P E, Harris J H, Hillman T J, Walker K F. The sustainable rivers audit: assessing river ecosystem health in the MurrayDarling Basin, Australia. Marine \& Freshwater Research, 2010, 61(7): 764-777

224. Xu Z, Wan S, Ren H, Han X, Li M H, Cheng W, Jiang Y. Effects of water and nitrogen addition on species turnover in temperate grasslands in northern China. PLoS One, 2012, 7(6): e39762

225. Covington W W, Fule P Z, Moore M M, Hart S C, Kolb T E, Mast J N, Sackett S S, Wagner M R. Restoring ecosystem health in ponderosa pine forests of the Southwest. Journal of Forestry, 1997, 95(4): 23-29

226. Hou F J, Xu L. History and current situation of ecosystem health research. Acta Prataculturae Sinica, 2009, 18(6): 210-225 (in Chinese)

227. Ren J Z. Study on the development strategy of animal husbandry in China.Beijing: China Prospect Press, 1988, 242-261 (in Chinese)

228. Ren J Z, Zhou X Y. Agri-eco-produetivity and its production potential. Acta Prapataculturae Sinca, 1995, 4: 1-5 (in Chinese)

229. Hou F, Li G, Chang S. Physiological indices of grazed grassland under health management. Journal of Applied Ecology Sinica, 2002, 13(8): 1049-1053 (in Chinese)

230. Han G, Zhao M, Hong M. Grassland ecosystem health and service and adaptive management. In: Wu J, Li F, eds. Lectures on modern ecology V: Macro ecology and sustainable science. Beijing: Higher Education Press, 2011, 217-243

231. Shan G, Xu Z, Ning F. Research progress and development trend of grassland ecosystem health assessment. Chinese Journal of Grassland, 2008, 30: 98-103 (in Chinese)

232. Whitford W G, De Soyza A G, Van Zee J W, Herrick J E, Havstad $\mathrm{K}$ M. Vegetation, soil, and animal indicators of rangeland health. Environmental Monitoring and Assessment, 1998, 51(1-2): 179200

233. Ren J Z, Nan Z B, Hao D. Interface theory in grass farming system. Acta Prapataculturae Sinica, 2000, 9: 1-8 (in Chinese)

234. Wang C T, Long R J, Wang Q L, Cao G M, Shi J J, Du Y G. Response of plant diversity and productivity to soil resources changing under grazing disturbance on an alpine meadow. Acta Ecologica Sinica, 2008, 28: 4144-4152 (in Chinese)

235. Li B. Grassland degradation in northern China and control measures. Chinese Agricultural Science, 1997, 30: 1-10 (in Chinese)

236. Ren J Z. The property, structure and health evaluation of grassland resources. In: Wang P, eds. Advances in Grassland Science in China. Beijing: China Agricultural University press, 1997

237. Hamilton Iii E W, Giovannini M S, Moses S A, Coleman J S, McNaughton S J. Biomass and mineral element responses of a Serengeti short-grass species to nitrogen supply and defoliation: compensation requires a critical [N]. Oecologia, 1998, 116(3): 407-418

238. Schaeffer D J. A toxicological perspective on ecosystem characteristics to track sustainable development. VII. Ecosystem health. Ecotoxicology and Environmental Safety, 1991, 22(2): 225-239

239. Jing X, Sanders N J, Shi Y, Chu H, Classen A T, Zhao K, Chen L, Shi Y, Jiang Y, He J S. The links between ecosystem multifunctionality and above- and belowground biodiversity are mediated by climate. Nature Communications, 2015, 6(1): 8159

240. Kang L, Han X, Zhang Z, Sun O J. Grassland ecosystems in China: review of current knowledge and research advancement. Philosophical Transactions of the Royal Society, 2007, 362(1482): 9971008 